\title{
STRUCTURAL CHARACTERIZATION OF KAEMPFEROL: A SPECTROSCOPIC AND COMPUTATIONAL STUDY
}

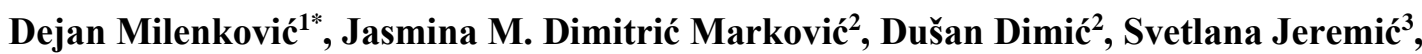 \\ Dragan Amić ${ }^{4}$, Marijana Stanojević Pirković ${ }^{5}$, Zoran S. Marković ${ }^{3}$ \\ ${ }^{1}$ Bioengineering Research and Development Center, 34000 Kragujevac, Republic of Serbia \\ ${ }^{2}$ Faculty of Physical Chemistry, University of Belgrade, Studentski trg 12-16, \\ 11000 Belgrade, Republic of Serbia \\ ${ }^{3}$ Department of Chemical-Technological Sciences, State University of Novi Pazar, \\ Vuka Karadžića bb, Novi Pazar, 36300, Republic of Serbia \\ ${ }^{4}$ Faculty of Agriculture, Josip Juraj Strossmayer University of Osijek, \\ Kralja Petra Svačića 1D, 31000 Osijek, Republic of Croatia \\ ${ }^{5}$ Faculty of Medical Sciences University of Kragujevac, Svetozara Markovića 69, \\ 34000 Kragujevac, Serbia \\ deki82@kg.ac.rs
}

Calculations based on the density functional theory, with the B3LYP functional and the 6$311++\mathrm{G}(\mathrm{d}, \mathrm{p})$ basis set, were performed with the aim of confirming the molecular structure and spectroscopic characteristics of kaempferol, a naturally occurring flavonoid molecule. The electronic structure of kaempferol was examined using NBO analysis. The assigning of the experimentally obtained IR and Raman spectra was performed after the best-fit-based comparison with theoretical spectra. The ${ }^{13} \mathrm{C}$ and ${ }^{1} \mathrm{H}$ NMR experimental spectra were related to the theoretically obtained values of the chemical shifts determined by the GIAO method. The correlation coefficient and the average absolute error values proved B3LYP-D3 to be an adequate method in describing the NMR parameters of kaempferol. Molecular docking analysis was carried out in order to identify the potency of inhibition of the title molecule against human procalcitonin. The inhibition activity was obtained for 10 conformations of ligand inside the protein.

Keywords: kaempferol; density functional theory; spectroscopic characterization; molecular docking

\section{СТРУКТУРНА КАРАКТЕРИЗАЦИЈА НА КАМФЕРОЛ: СПЕКТРОСКОПСКИ И КОМПЈУТЕРСКИ ИСПИТУВАЫА}

\begin{abstract}
Извршени се пресметки базирани на теоријата на густина на функционалот со функционалот B3LYP и основниот сет $6-311++\mathrm{G}(\mathrm{d}, \mathrm{p})$ со цел да се потврдат молекулската структура и спектроскопските карактеристики на камферол, флавоноидна молекула од природно потекло. Електронската структура беше испитана со NBO анализа. Асигнацијата на експериментално добиените IR и рамански спектри беше извршена со најдобро усогласената споредба со теоретските спектри. Експерименталните спектри ${ }^{13} \mathrm{C}$ и ${ }^{1} \mathrm{H}$ NMR беа споредени со теоретски добиените вредности на хемиските поместувања определени со методот GIAO. Коефициентот на корелација и просечните вредности на апсолутната грешка покажаа дека B3LYPD3 e соодветен метод за опишување на NMR-параметрите на камферол. Анализата на припојување беше извршена со цел да се идентификува способноста за инхибиција на ова соединение со хуман прокалцитонин. Инхибициската активност беше добиена за 10 конформации на лигандот внатре во протеинот.
\end{abstract}

Клучни зборови: камферол; теорија на густина на функционалот; спектроскопско молекулско припојување 


\section{INTRODUCTION}

Flavonoids, as natural polyphenolic compounds, are reported to exert a wide range of positive health effects arising mainly from their antioxidant ability. They represent an important group of phytochemicals with over 8000 individual compounds known. They have roles as antioxidants, antimicrobials, receptors and screening molecules for light, visual attractors and feeding repellents. Flavonoids are common in everyday human diet, as their presence indicates good-quality food, flavor identification, and taste thresholds influencing food preference $[1,2]$. The fact that flavonoids are recognized as highly potent external defense components against oxidative stress in various stages, makes them some of the most widely investigated biochemically active molecules today [3].

Many studies on flavonoids have shown that they exhibit prominent therapeutic and pharmacological activities, among which their antiallergenic, antiviral, anti-inflammatory and vasodilating properties are particularly interesting. Most studies into antioxidant activity are related to their structural features: the carbon-carbon double bond in position 2, an $\mathrm{OH}$ group in position 3 , $\mathrm{OH}$ groups present in the $\mathrm{A}$ and $\mathrm{B}$ rings, and $\mathrm{AC}-\mathrm{B}$ ring coplanarity [4-16]. However, it has been found that, under the specific conditions, some can exhibit prooxidant activity as well [12].

Kaempferol (3,5,7-trihydroxy-2-(4'-hydroxyphenyl)-4H-chromen-4-one; Fig. 1) is a natural flavonoid that can be found mainly in vegetables (broccoli, cabbage, leek, beans, tomato), fruits (strawberries, grapes), tea, gingko, and in many medical herbs used in traditional medicine [3, 17]. Known as a strong antioxidant, kaempferol helps in the prevention of arteriosclerosis, inhibits the oxidation of low-density lipoproteins and lowers the aggregation of platelets in the blood. It reduces the risk of cancer development (including pancreatic, lung and gastric cancer and ovarian cancer in women) by inhibiting angiogenesis in vitro and/or in vivo [3]. Kaempferol has proven its pharmacological activity as good radical scavenger in patients with diabetes, asthma and carcinogenesis [18]. It also inhibits enzymes such as cyclooxygenases (COXs), lipoxygenases (LOXs), and induces nitric oxide synthase (iNOS) known to be present during the process of inflammation [3].

Numerous authors characterize an investigated compound by comparing theoretical and experimental results [19-21]. The aim of this study is to contribute to the elucidation of the structure of kaempferol by using quantum chemical calcula- tions at the B3LYP-D3 level of theory in conjunction with different spectroscopic methods (IR, Raman and ${ }^{1} \mathrm{H}$ and ${ }^{13} \mathrm{C}$ NMR).

In addition, kaempferol is investigated for its reactivity toward human procalcitonin (PCT) protein by means of molecular docking analysis. PCT $(\sim 13 \mathrm{kDa})$ is a peptide consisting of 116 amino acids. This protein is degraded enzymatically into lower-molecular-weight peptides. Calcitonin is the final product and consists of 32 amino acids. In the serum of healthy humans, all precursors can be detected, including PCT and the mature peptide hormone. In septic patients, the PCT in serum contains a peptide of only 114 amino, instead of the predicted PCT of 116 amino acids in healthy patients [22]. The biological effect of this protein was proven in the study of Nylén et al., who showed that the elevated concentrations can lead to sepsis, but can be treated by anti-PCT antibodies [23].

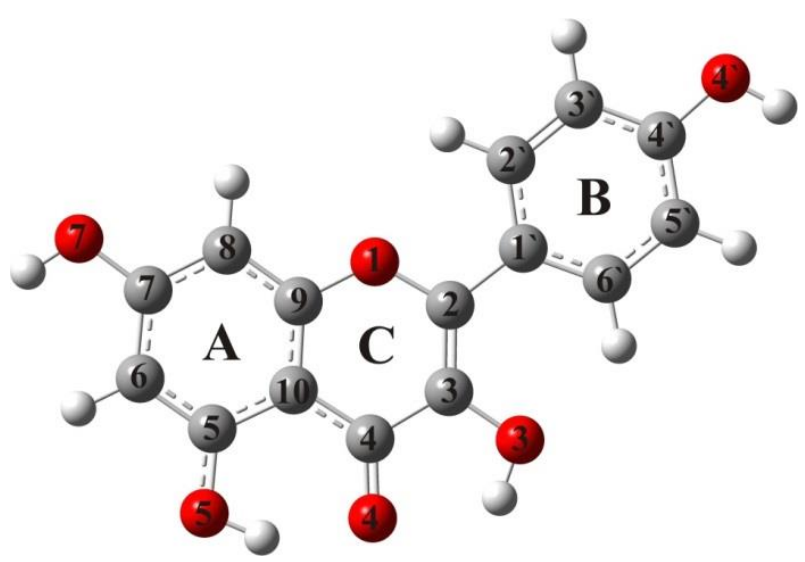

Fig. 1. The optimized structure and numbering of kaempferol

\section{EXPERIMENTAL SECTION}

\subsection{Materials}

Kaempferol and potassium bromide $(\mathrm{KBr}$, IR grade) were obtained from Aldrich. Both chemicals were used without further purification.

\subsection{IR, Raman and NMR spectra}

The IR spectrum of kaempferol was recorded on a Thermo Nicolet 6700 FT-IR spectrometer equipped with ATR and DTGS TEC detectors. The experimental parameters were the following: spectral resolution $2 \mathrm{~cm}^{-1}$, number of sample scans 512 and the number of background scans 512. The investigated molecule was studied in $\mathrm{KBr}$ matrix in a kaempferol/KBr ratio of $1: 200$. The IR spectrum was recorded in the $4000-400 \mathrm{~cm}^{-1}$ region. The 
Raman spectrum was recorded on a Thermo Scientific DXR Raman spectrometer. The excitation source was a high-brightness diode-pumped solidstate laser with wavelength $532 \mathrm{~nm}$. The objective lens was set to the value of $50 \times$. A spectrograph with a 900 lines $\mathrm{mm}^{-1}$ grating was used for analysis of the scattered light. The spectrum was obtained between 3400 and $400 \mathrm{~cm}^{-1}$ directly from the pure powder samples. The output of the laser was fixed at $10 \mathrm{~mW}$ with an acquisition time of $10 \mathrm{~s}$ with 10 scans. Fluorescence was corrected for, and data acquisition and processing was performed with Thermo Scientific OMNIC software.

The theoretical Raman intensities $\left(I_{i}^{R}\right)$ were derived based on the Raman scattering activities:

$$
I_{i}^{R}=C\left(v_{0}-v_{i}\right)^{4} \cdot v_{i}^{-1} \cdot B_{i}^{-1} \cdot S_{i}
$$

The quantity $B_{i}$ is a temperature factor that includes the contribution of the excited vibrational states, as predicted by the Boltzmann distribution:

$$
B_{i}=1-\exp \left(-\frac{h v_{i} c}{k T}\right)
$$

where $h, k, c$ and $\mathrm{T}$ are the Planck and Boltzmann constants, the speed of light and temperature, respectively. The wavenumber of the laser excitation line is $v_{0} \quad\left(v_{0}=18797 \mathrm{~cm}^{-1}\right.$ corresponding to $532 \mathrm{~nm}), v_{i}$ is the wavenumber of the normal mode $\left(\mathrm{cm}^{-1}\right)$, while $S_{i}$ is the Raman scattering activity of the normal mode $Q_{i}$. The calculated Raman intensity, $I_{i}^{R}$, is presented in arbitrary units ( $C$ is a constant equal to $10^{-12}$ ). Because of the low contribution of the excited vibrational states, the value of $B_{i}$ is assumed to be 1. Otherwise, as is reported in the literature, the calculated Raman intensities for the bands below $300 \mathrm{~cm}^{-1}$ were overestimated when compared to the experimental values [24].

NMR spectra, in DMSO-d6 with TMS as internal standard, were determined on a Varian Gemini $200 \mathrm{MHz}$ NMR spectrometer $\left({ }^{1} \mathrm{H}\right.$ at $200 \mathrm{MHz}$ and ${ }^{13} \mathrm{C}$ at $50 \mathrm{MHz}$ ).

\section{THEORETICAL BACKGROUND}

Optimization of the geometry of kaempferol was performed by using a B3LYP-D3 local density functional method and the $6-311++\mathrm{G}(\mathrm{d}, \mathrm{p})$ basis set, as implemented in the Gaussian 09 package [25-28]. This functional has been successfully reported in the literature for similar compounds [29, 30]. B3LYP-D3 was selected as a method widely applied for the NMR chemical shifts of similar molecules that has proved to predict the interatomic interactions at short and medium distances $(\leq 5$ $\AA)$ more accurately and reliably than traditional DFT methods. Hybrid GGA B3LYP-D3 included an empirical correction term proposed by Grimme $[31,32]$ and the stability of the obtained structure was verified to be the minimum on the potential energy surface. The calculated wavenumbers were scaled by a factor of 0.9873 in order to obtain a better match between the calculated and the experimental wavenumber values. For the prediction of IR and Raman spectra, the optimized gas-phase geometry was used. PED (Potential Energy Distribution) analysis using VEDA software was applied for estimation and assignation of the vibrational modes [33. 34]. The ${ }^{1} \mathrm{H}$ and ${ }^{13} \mathrm{C}$ chemical shifts were predicted by means of the GIAO (Gauge Independent Atomic Orbital) method, as implemented in Gaussian 09 with DMSO as solvent [35]. The NBO analysis was performed by using NBO 5.9 software [36, 37]. The polarizability and hyperpolarizability tensors $\left(\alpha_{x x}, \alpha_{x y}, \alpha_{y y}, \alpha_{x z}, \alpha_{y z}, \alpha_{z z}\right.$ and $\left.\beta_{\mathrm{xxx}}, \beta_{\mathrm{xxy}}, \beta_{\mathrm{xyy}}, \beta_{\mathrm{yyy}}, \beta_{\mathrm{xxz}}, \beta_{\mathrm{xyz}}, \beta_{\mathrm{yyz}}, \beta_{\mathrm{xzz}}, \beta_{\mathrm{yzz}}, \beta_{\mathrm{zzz}}\right)$ can be obtained by a Gaussian frequency job output file. The molecular docking simulation was carried out using AutoDock 4.0 software [38]. The structure of human PCT was adapted from literature data [39]. Discovery Studio 4.0 was used for the preparation of protein for docking by removing the co-crystallized ligand, water molecules and cofactors [40]. To calculate Kollman charges and to add polar hydrogen, the AutoDockTools (ADT) graphical user interface was applied. Kaempferol was prepared for docking by minimizing its energy at the previously mentioned level of theory. The flexibility of the ligands was considered, while the protein or biomolecules remained as rigid structures in ADT. All kaempferol bonds were set to be rotatable. The Geistenger method for calculation of partial charges was employed. All calculations for protein-ligand flexible docking were performed using the Lamarckian Genetic Algorithm (LGA) method. A grid box with dimensions $92.007 \AA \times$ $0.202 \AA \times 0.111 \AA$ of human PCT was used in order to cover the protein binding site and to enable the ligands to move freely. Inhibition potency of kaempferol was investigated and discussed.

\section{RESULTS AND DISCUSSION}

\subsection{Molecular geometry of kaempferol}

The structure of kaempferol (Fig. 1) was optimized using B3LYP-D3 functional. Due to the 
lack of X-ray crystallographic structural data of pure kaempferol (to the best of our knowledge) the DAPK1-kaempferol complex (PDB code: 5AUX) structure was used [41], with the isolated parameters for the molecule of interest. Because of the rigidity of the molecule, it is expected that the structural parameters in the complex do not change significantly [42]. The most stable conformation of kaempferol was taken from our previous work [43, 44]. The calculated and experimental bond lengths are listed in Table 1.
Table 1 shows that B3LYP-D3 reproduces excellently the bond lengths of kaempferol with a mean correlation coefficient (R) of 0.991 and an average absolute error (AAE) for bond length of $0.012 \AA$. The optimized and experimental bond angles are given in Table S1 in the Supporting Information. The theoretical data indicate that kaempferol is planar $\left(\tau\left(\mathrm{C} 3-\mathrm{C} 2-\mathrm{Cl}^{\prime}-\mathrm{C} 2{ }^{\prime}\right)\right.$ is 0.0$)$ (Table S1). On the other hand, the experimentally determined dihedral angle between $\mathrm{B}$ and $\mathrm{C}$ rings amounts to $168.9^{\circ}$.

Table 1

The bond lengths in the neutral molecule, optimized with the B3LYP-D3/6-311++G(d,p) model (the atom numbering is in line with Figure 1). Experimental values are also included.

\begin{tabular}{|c|c|c|}
\hline \multirow{2}{*}{ Bond length $/ \AA$} & \multicolumn{2}{|c|}{ Kaempferol } \\
\hline & Experimental & B3LYP \\
\hline $\mathrm{D}(\mathrm{C} 2-\mathrm{O} 1)$ & 1.365 & 1.373 \\
\hline $\mathrm{D}(\mathrm{C} 2-\mathrm{C} 3)$ & 1.399 & 1.368 \\
\hline $\mathrm{D}\left(\mathrm{C} 2-\mathrm{C} 1^{\prime}\right)$ & 1.400 & 1.462 \\
\hline $\mathrm{D}(\mathrm{C} 3-\mathrm{C} 4)$ & 1.391 & 1.450 \\
\hline $\mathrm{D}(\mathrm{C} 3-\mathrm{O} 3)$ & 1.363 & 1.357 \\
\hline $\mathrm{D}(\mathrm{C} 4-\mathrm{C} 10)$ & 1.391 & 1.434 \\
\hline $\mathrm{D}(\mathrm{C} 4-\mathrm{O} 4)$ & 1.235 & 1.256 \\
\hline $\mathrm{D}(\mathrm{C} 10-\mathrm{C} 5)$ & 1.398 & 1.422 \\
\hline $\mathrm{D}(\mathrm{C} 10-\mathrm{C} 9)$ & 1.393 & 1.405 \\
\hline $\mathrm{D}(\mathrm{C} 5-\mathrm{C} 6)$ & 1.392 & 1.387 \\
\hline $\mathrm{D}(\mathrm{C} 5-\mathrm{O} 5)$ & 1.362 & 1.341 \\
\hline $\mathrm{D}(\mathrm{C} 6-\mathrm{C} 7)$ & 1.391 & 1.402 \\
\hline $\mathrm{D}(\mathrm{C} 7-\mathrm{C} 8)$ & 1.391 & 1.393 \\
\hline $\mathrm{D}(\mathrm{C} 7-\mathrm{O} 7)$ & 1.363 & 1.360 \\
\hline $\mathrm{D}(\mathrm{C} 8-\mathrm{C} 9)$ & 1.392 & 1.388 \\
\hline $\mathrm{D}(\mathrm{C} 9-\mathrm{O} 1)$ & 1.369 & 1.358 \\
\hline $\mathrm{D}\left(\mathrm{Cl}^{-}-\mathrm{C} 2{ }^{\prime}\right)$ & 1.394 & 1.407 \\
\hline $\mathrm{D}\left(\mathrm{C} 2^{\prime}-\mathrm{C} 3^{\prime}\right)$ & 1.393 & 1.389 \\
\hline $\mathrm{D}\left(\mathrm{C} 3^{`}-\mathrm{C} 4^{\prime}\right)$ & 1.394 & 1.396 \\
\hline $\mathrm{D}\left(\mathrm{C} 44^{\prime}-\mathrm{C} 5^{\prime}\right)$ & 1.389 & 1.397 \\
\hline $\mathrm{D}\left(\mathrm{C} 4{ }^{`}-\mathrm{O} 4\right)$ & 1.357 & 1.364 \\
\hline $\mathrm{D}\left(\mathrm{C} 5^{-}-\mathrm{C} 6^{\prime}\right)$ & 1.391 & 1.384 \\
\hline $\mathrm{D}\left(\mathrm{Cl}-\mathrm{C} 6{ }^{\prime}\right)$ & 1.390 & 1.410 \\
\hline $\mathrm{D}\left(\mathrm{O} 44^{`}-\mathrm{H} 4{ }^{\prime}\right)$ & 0.950 & 0.963 \\
\hline $\mathrm{D}(\mathrm{O} 3-\mathrm{H} 3)$ & 0.950 & 0.976 \\
\hline $\mathrm{D}(\mathrm{O} 5-\mathrm{H} 5)$ & 0.950 & 0.986 \\
\hline $\mathrm{D}(\mathrm{O} 7-\mathrm{H} 7)$ & 0.950 & 0.963 \\
\hline $\mathrm{D}_{\mathrm{H}}(\mathrm{O} 3-\mathrm{H} 3---\mathrm{O} 4)$ & l & 2.032 \\
\hline $\left.\mathrm{DH}_{\mathrm{H}} \mathrm{O} 5-\mathrm{H} 5---\mathrm{O} 4\right)$ & 1.718 & 1.777 \\
\hline $\mathbf{R}$ & \multicolumn{2}{|c|}{0.991} \\
\hline Average absolute error (AAE) & \multicolumn{2}{|c|}{0.012} \\
\hline
\end{tabular}


The deviation of the $\mathrm{B}$ ring from planarity is probably caused by the repulsion between $\mathrm{H} 3$ and H6` hydrogen atoms. If the known differences between the vacuum and condensed-phase environments are taken into the account, this discrepancy can be ascribed to the packing in the DAPK1kaempferol complex (Fig. 2).

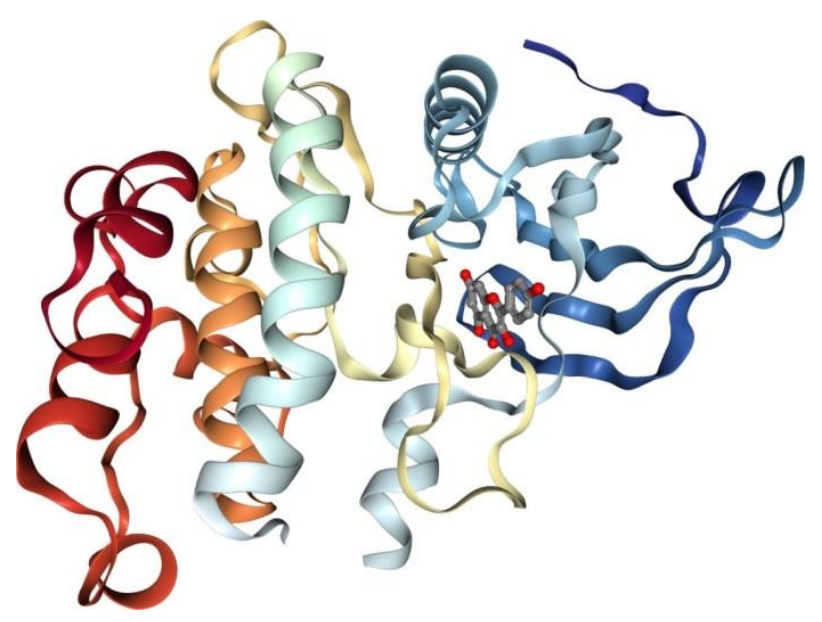

Fig. 2. Crystal structure of DAPK1-kaempferol complex (PDB code: 5 AUX)

\subsection{NBO analysis}

The electronic structure of kaempferol was examined using NBO analysis. In order to evaluate the donor-acceptor interactions, analysis of the second-order Fock matrix was performed. The stabilization energy $\left(E^{(2)}\right)$ for each donor (i) and acceptor (j) associated with the delocalization between $i$ and $j$ is determined as:

$$
E^{(2)}=\Delta E_{i j}=q_{i} \frac{\left(F_{i j}\right)^{2}}{\left(E_{j}-E_{i}\right)}
$$

where $q_{\mathrm{i}}$ is the donor orbital occupancy, $E_{i}, E_{j}$ are the diagonal elements (orbital energies) and $F_{i, j}$ is the off-diagonal NBO Fock matrix element. The large $E^{(2)}$ value indicates the intensive interaction between the electron-donors and electron-acceptors and the greater extent of conjugation of the whole system. The possible intensive interactions are given in Table 2.

The most important interaction (n- $\left.\pi^{*}\right)$ energy, related to resonance in the molecule, is electron donation from the LP2 $(\mathrm{O})$ atom orbitals to the an- tibonding acceptor $\pi^{*}(\mathrm{C}-\mathrm{C})$ of the phenyl ring $\left(\mathrm{LP} 2(\mathrm{O} 5) \rightarrow \pi^{*}(\mathrm{C} 5-\mathrm{C} 6) \quad\left(159.2 \mathrm{~kJ} \mathrm{~mol}^{-1}\right)\right)$. This large interaction energy indicates hyperconjugation between the electron-donating oxygen atom and the phenyl ring. Also, the other oxygen lone electron pairs show a significant electron-donating ability to the antibonding acceptor $\pi^{*}(\mathrm{C}-\mathrm{C})$ orbital of the phenyl ring. Besides LP2 $(\mathrm{O}) \rightarrow \pi^{*}(\mathrm{C}-\mathrm{C})$ and $\mathrm{LP} 2(\mathrm{O}) \rightarrow \sigma^{*}(\mathrm{C}-\mathrm{C})$ interactions, strong intramolecular hyperconjugative interactions are formed by orbital overlap between $\pi(\mathrm{C}-\mathrm{C}) \rightarrow$ $\pi^{*}(\mathrm{C}-\mathrm{C})$ bond orbitals, resulting in intramolecular charge transfer (ICT), which causes stabilization of the system. These interactions lead to an increase in electron density (ED) in the $\mathrm{C}-\mathrm{C}$ antibonding orbitals, which weakens their respective bonds. The EDs at the conjugated $\pi(\sim 1.63-1.76 \mathrm{e})$ and $\pi^{*}$ bonds $(\sim 0.3-0.4 \mathrm{e})$ of the phenyl and $\alpha$-pyrone rings clearly demonstrate strong electron delocalization, leading to stabilization by $\sim 43-144 \mathrm{~kJ} \mathrm{~mol}^{-1}$.

The kaempferol structure is characterized by two intramolecular hydrogen bonds (IHBs) which additionally stabilize the structure. The NBO analysis revealed that the lone pair-antibonding orbital interactions between the carbonyl oxygen and the adjacent $\mathrm{O}-\mathrm{H}$ bonds are responsible for the hydrogen-bond formation. Since the $\mathrm{O} 4(2 p)$ and $\mathrm{O} 4(1 p)$ orbitals are abundant in electrons, while the O5$\mathrm{H} 5\left(\sigma^{*}\right)$ orbital is electron-deficient, it was found that charge transfer from the $\mathrm{O} 4(2 p)$ to the O5$\mathrm{H} 5\left(\sigma^{*}\right)$ orbital is a favorable donor-acceptor interaction with stabilization energy of $57.61 \mathrm{~kJ} \mathrm{~mol}^{-1}$. This has a significant effect on the strength of the hydrogen-bond delocalization energy. Also, there is significantly weaker charge transfer from $\mathrm{O} 4(1 p)$ to $\mathrm{O} 5-\mathrm{H} 5\left(\sigma^{*}\right)$ (Table 2$)$. These findings are in accord with the IHB lengths, and the decrease in strength with bond elongation is proven (see Table 1). These are weaker interactions and the secondorder interaction energies are proportional to the hydrogen-bond strengths.

The $\mathrm{C} 2-\mathrm{C} 1^{\prime}$ bond length of about $1.462 \AA$ (Table 1) lies between the bond lengths characteristic of aromatic and single $\mathrm{C}-\mathrm{C}$ bonds, indicating weak electron delocalization between the $\mathrm{B}$ and $\mathrm{C}$ rings. This assumption is supported by the NBO analysis. A slightly greater $p$-orbital contribution to $\mathrm{C}^{\prime}{ }^{\prime}$ in the $\mathrm{C} 2-\mathrm{C}^{\prime}$ bond (hybrid composition $0.710\left(\mathrm{sp}^{1.66}\right) \mathrm{C} 2+0.704\left(\mathrm{sp}^{2.18}\right) \mathrm{C} 1$ ') could be the main reason for this bond being slightly longer than a double bond. 
Table 2

Second-order perturbation theory analysis of the kaempferol Fock matrix

\begin{tabular}{|c|c|c|c|c|c|c|}
\hline Donor $(i)$ & Acceptor $(j)$ & $\mathrm{ED}(i)$ & $\mathrm{ED}(j)$ & $\begin{array}{l}E^{(2)} \\
\mathrm{kJmol}^{-1} \\
\end{array}$ & $\begin{array}{l}E_{i}-E_{j} \\
\text { a.u. }\end{array}$ & $\begin{array}{l}F_{i, j} \\
\text { a.u. }\end{array}$ \\
\hline$\pi \mathrm{C5}-\mathrm{C6}$ & $\pi * \mathrm{C} 7-\mathrm{C} 8$ & 1.69 & 0.40 & 116.9 & 0.28 & 0.08 \\
\hline$\pi \mathrm{C5}-\mathrm{C6}$ & $\pi^{*} \mathrm{C} 9-\mathrm{C} 10$ & 1.69 & 0.48 & 51.21 & 0.27 & 0.05 \\
\hline$\pi \mathrm{C} 7-\mathrm{C8}$ & $\pi * \mathrm{C} 5-\mathrm{C} 6$ & 1.66 & 0.36 & 53.09 & 0.28 & 0.05 \\
\hline$\pi \mathrm{C} 7-\mathrm{C8}$ & $\pi * \mathrm{C} 9-\mathrm{C} 10$ & 1.66 & 0.48 & 123.4 & 0.27 & 0.08 \\
\hline$\pi \mathrm{C9}-\mathrm{C10}$ & $\pi * \mathrm{C} 5-\mathrm{C} 6$ & 1.63 & 0.36 & 102.8 & 0.29 & 0.08 \\
\hline$\pi \mathrm{C9}-\mathrm{C10}$ & $\pi^{*} \mathrm{C} 7-\mathrm{C} 8$ & 1.63 & 0.40 & 52.30 & 0.29 & 0.05 \\
\hline$\pi \mathrm{C9}-\mathrm{C10}$ & $\pi^{*} \mathrm{O} 4-\mathrm{C} 4$ & 1.63 & 0.41 & 143.8 & 0.26 & 0.09 \\
\hline$\pi \mathrm{C} 2-\mathrm{C} 3$ & $\pi^{*} \mathrm{O} 4-\mathrm{C} 4$ & 1.76 & 0.41 & 103.2 & 0.28 & 0.08 \\
\hline$\pi \mathrm{C} 2-\mathrm{C} 3$ & $\pi^{*} \mathrm{C} 1^{`}-\mathrm{C} 6{ }^{\circ}$ & 1.76 & 0.40 & 43.30 & 0.32 & 0.05 \\
\hline$\pi \mathrm{C} 1-\mathrm{C} 6$ & $\pi^{*} \mathrm{C} 2-\mathrm{C} 3$ & 1.63 & 0.31 & 78.62 & 0.27 & 0.06 \\
\hline$\pi \mathrm{C} 1-\mathrm{C6}$ & $\pi^{*} \mathrm{C} 2^{`}-\mathrm{C} 3^{\prime}$ & 1.63 & 0.30 & 90.00 & 0.28 & 0.07 \\
\hline$\pi \mathrm{C} 1-\mathrm{C6}$ & $\pi^{*} \mathrm{C} 4-\mathrm{C} 5$ & 1.63 & 0.39 & 73.30 & 0.27 & 0.06 \\
\hline$\pi \mathrm{C} 2-\mathrm{C} 3$ & $\pi^{*} \mathrm{C} 1^{`}-\mathrm{C} 6{ }^{`}$ & 1.70 & 0.40 & 66.19 & 0.28 & 0.06 \\
\hline$\pi \mathrm{C} 2{ }^{\circ}-\mathrm{C} 3$ & $\pi * \mathrm{C} 4-\mathrm{C} 5$ & 1.70 & 0.39 & 95.31 & 0.27 & 0.07 \\
\hline$\pi \mathrm{C} 4-\mathrm{C} 5$ & $\pi^{*} \mathrm{C} 1^{`}-\mathrm{C} 6{ }^{\circ}$ & 1.64 & 0.40 & 101.9 & 0.29 & 0.08 \\
\hline$\pi \mathrm{C} 4-\mathrm{C} 5$ & $\pi^{*} \mathrm{C} 2^{`}-\mathrm{C} 3^{\prime}$ & 1.64 & 0.30 & 64.10 & 0.29 & 0.06 \\
\hline LP1 07 & $\sigma^{*} \mathrm{C} 6-\mathrm{C} 7$ & 1.98 & 0.02 & 24.60 & 1.16 & 0.07 \\
\hline LP2 O7 & $\pi * \mathrm{C} 7-\mathrm{C} 8$ & 1.86 & 0.40 & 123.9 & 0.35 & 0.10 \\
\hline LP1 O5 & $\sigma^{*} \mathrm{C} 5-\mathrm{C} 10$ & 1.98 & 0.03 & 26.90 & 1.09 & 0.08 \\
\hline LP2 05 & $\pi * \mathrm{C} 5-\mathrm{C} 6$ & 1.82 & 0.36 & 159.2 & 0.33 & 0.11 \\
\hline LP1 O4 & $\sigma^{*} \mathrm{H} 5-\mathrm{O}$ & 1.97 & 0.31 & 11.56 & 1.20 & 0.05 \\
\hline LP2 O4 & $\sigma^{*} \mathrm{H} 5-\mathrm{O} 5$ & 1.87 & 0.04 & 57.61 & 0.69 & 0.09 \\
\hline LP2 O4 & $\sigma^{*} \mathrm{H} 3-\mathrm{O} 3$ & 1.87 & 0.02 & 14.31 & 0.69 & 0.05 \\
\hline LP2 04 & $\sigma^{*} \mathrm{C} 4-\mathrm{C} 10$ & 1.87 & 0.05 & 55.19 & 0.78 & 0.09 \\
\hline LP2 O4 & $\sigma * \mathrm{C} 3-\mathrm{C} 4$ & 1.87 & 0.06 & 69.50 & 0.74 & 0.10 \\
\hline LP2 O1 & $\pi^{*} \mathrm{C} 9-\mathrm{C} 10$ & 1.76 & 0.48 & 125.9 & 0.36 & 0.10 \\
\hline LP2 01 & $\pi * \mathrm{C} 2-\mathrm{C} 3$ & 1.76 & 0.31 & 114.9 & 0.37 & 0.09 \\
\hline LP2 O3 & $\pi * \mathrm{C} 2-\mathrm{C} 3$ & 1.87 & 0.31 & 124.4 & 0.34 & 0.09 \\
\hline LP1 O4 & $\sigma^{*} \mathrm{C} 4-\mathrm{C} 5$ & 1.98 & 0.03 & 25.61 & 1.17 & 0.08 \\
\hline LP2 O4 & $\pi^{*} \mathrm{C} 4-\mathrm{C} 5$ & 1.87 & 0.39 & 119.6 & 0.35 & 0.10 \\
\hline
\end{tabular}

\subsection{Electrostatic potential and charge distribution}

The charge distribution in molecules is usually represented by a map of electrostatic potential (MEP). This is a useful feature to study reactive sites on the surface of the molecule, given that an approaching electrophile would be attracted to negative regions (electron-rich/red color) while the positive region (electron-poor/blue color) would be a preferred site for nucleophilic attack. MEP offers more intuitive way to understand the polarity of a molecule by correlating it with the molecular structure and the physicochemical properties [45-50]. The MEP of kaempferol is presented in Figure 3a.

The MEP in the case of the investigated molecule (Fig. 3a) clearly indicates that the chromene oxygen atom 4 , as well as oxygen atoms $3,5,7$ and $4^{\prime}$, contribute to the most electronega- tive regions (red). Due to the excess negative charge, one can expect a relatively high nucleophilic activity of this part of the molecule. This is in agreement with the fact that the negative regions of the MEP contain the electronegative atoms with the lone electron pairs. On the other hand, the positive MEP values are localized over the hydrogen atoms bonded to oxygen atoms.

The NBO analysis of the investigated compound was also performed. The obtained values of the natural charge distribution are presented in Figure $3 b$ and are in accordance with MEP data. As expected, the negative charge is distributed mainly over the oxygen atoms attached to the benzene rings $\mathrm{A}$ and $\mathrm{B}$ as well as chromene ring $\mathrm{C}$, while the rest of the negative natural charge is delocalized mostly over $\mathrm{C} 6, \mathrm{C} 8, \mathrm{C} 10$ in the $\mathrm{A}$ ring and over $\mathrm{C}$ atoms in the $\mathrm{B}$ ring. 


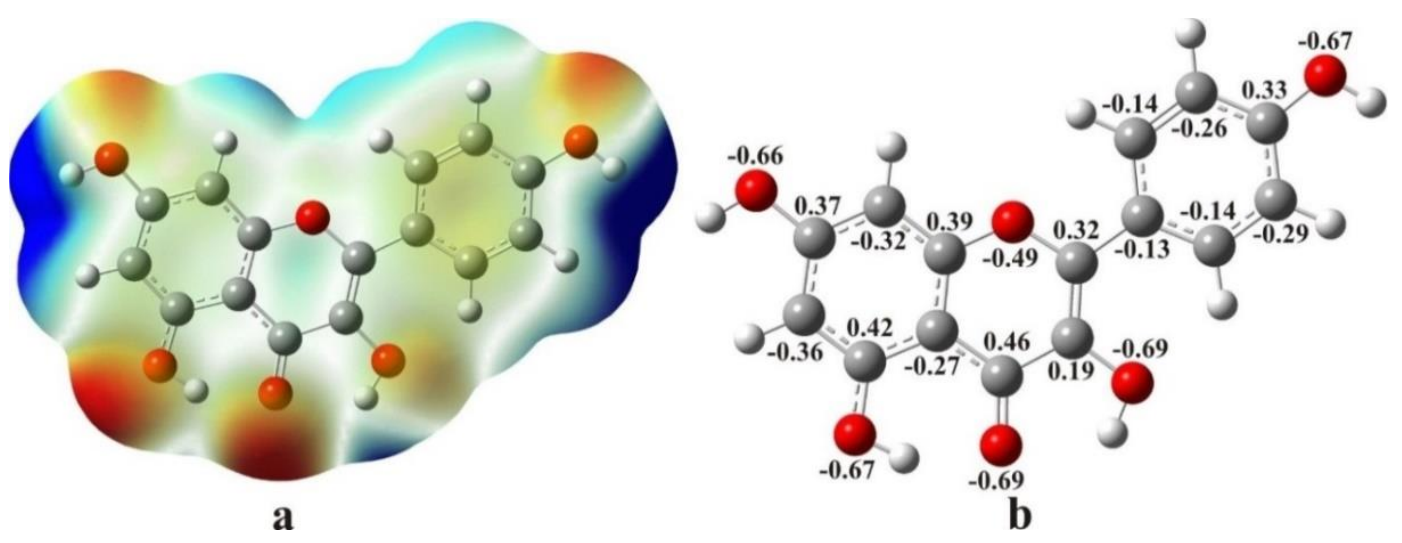

Fig. 3. Molecular electrostatic potential surface (left) and the natural charge distribution (right)

The $\mathrm{C} 4$ atom has greater positive charge than other $\mathrm{C}$ atoms in the chromene part of the molecule. In addition, the $\mathrm{C} 5$ atom has more positive value than other atoms in the $\mathrm{A}$ and $\mathrm{B}$ rings. On the other hand, a slightly positive natural charge is distributed almost uniformly over the hydrogen atoms. The obtained results indicate that the $\mathrm{H}$ atoms bonded to $\mathrm{O} 7$ and $\mathrm{O}^{\prime}$ ' have more positive values than the other hydrogen atoms.

\subsection{Nonlinear optical activity}

The polarizabilities and the first-order hyperpolarizabilities of kaempferol were calculated using the DFT/B3LYP-D3 method with the 6$311++\mathrm{G}(\mathrm{d}, \mathrm{p})$ basis set in order to investigate the relationship between molecular structure and nonlinear optical properties (NLO). The calculated polarizability and the first hyperpolarizability $(\beta)$ of kaempferol were based on the finite-field approach. The total electric dipole moment $(\mu)$, mean polarizability $(\Delta \alpha)$ and the total first-order static hyperpolarizability $\left(\beta_{\text {total }}\right)$, were calculated using the $\mathrm{x}, \mathrm{y}$ and $\mathrm{z}$ components of these electric moments [51]. It is well known that higher values of dipole moment, molecular polarizability and firstorder hyperpolarizability are important for the more pronounced NLO properties of a compound. The calculated total electric dipole moment $(\mu)$, mean polarizability $(\alpha)$ and total first-order static hyperpolarizability $\left(\beta_{\text {total }}\right)$ and their components are presented in Table S2. In the present case, the calculated total dipole moment of kaempferol is $1.78 \mathrm{D}$. The predicted value of the linear polarizability $\left(\alpha_{\text {tot }}\right)$ and total first-order static hyperpolarizability $\left(\beta_{\text {total }}\right)$ are found to be $33.539 \times 10^{-24}$ esu and $28.428 \times 10^{-30}$ esu, respectively. The calculated value of $\beta_{\text {total }}$ of kaempferol is 150 times higher than that of urea $\left(0.1947 \times 10^{-30} \mathrm{esu}\right)$ [52], which is one of the prototypical molecules used in the study of the NLO properties of molecular systems and the value frequently used as a threshold for comparative purposes. Remarkably, the high polarizability of kaempferol shows its drug-likeliness as the high polarizability allows it to bind with its target very strongly.

\subsection{Vibrational spectra of kaempferol}

The experimentally obtained, theoretically calculated and scaled wavenumbers, with the assignments for the first 65 vibrational modes (of 87) in the region $3700-400 \mathrm{~cm}^{-1}$, are presented in Table 3 , together with the relative descriptions of IR and Raman intensities, PED values and the description of the largest vibrational contributions to the normal modes. The kaempferol geometry optimized in the gas phase served as the basis for calculation of the IR and Raman spectra using the B3LYP-D3/6$311++\mathrm{G}(\mathrm{d}, \mathrm{p})$ model. The B3LYP-D3/6$311++\mathrm{G}(\mathrm{d}, \mathrm{p})$-calculated wavenumbers were corrected using a vibrational scaling factor value of 0.9873 .

These calculated values are further discussed. The scaling factor was determined by the least-squares method, on the basis of the experimental data for the IR spectrum.

The most distinct bands in the IR spectrum of kaempferol are those in high-frequency region (4000-2000 $\mathrm{cm}^{-1}$; Figure S1 in Supplementary Information) assigned to different modes of $\mathrm{O}-\mathrm{H}$ and $\mathrm{C}-\mathrm{H}$ vibrations. This region in the experimental spectrum is dominated by two overlapping and very strong-intensity bands, at 3420 and $3206 \mathrm{~cm}^{-1}$. These intense bands could be taken as possible, different, absorptions by hydrogen bonds in kaempferol. This is the result confirmed by NBO analysis. Due to rather significant differences in wavenumber compared to the value predicted by DFT $\left(3340 \mathrm{~cm}^{-1}\right.$, the scaled value) the experimentally obtained band at $3420 \mathrm{~cm}^{-1}$ is assigned to the $\mathrm{O}-\mathrm{H}$ stretching vibration, mode 84 (Table 3 ). 
T a ble 3

Experimental and calculated positions of the bands in the IR and Raman spectra of kaempferol, with assignments and intensities of the normal modes

\begin{tabular}{|c|c|c|c|c|c|c|c|c|c|}
\hline \multirow[b]{2}{*}{ Mod } & \multirow[b]{2}{*}{ Assignments } & \multicolumn{2}{|c|}{ Exp. values } & \multicolumn{6}{|c|}{ B3LYP-D3/6-311++g(d,p) } \\
\hline & & $\begin{array}{l}\text { IR } \\
\mathrm{cm}^{-1}\end{array}$ & $\begin{array}{l}\text { Raman } \\
\mathrm{cm}^{-1}\end{array}$ & $\begin{array}{l}\text { Unscaled } \\
\text { freq. } \\
\mathrm{cm}^{-1}\end{array}$ & $\begin{array}{l}\text { Scaled } \\
\text { freq. } \\
\mathrm{cm}^{-1}\end{array}$ & $\begin{array}{l}\text { IR } \\
\text { intens. }\end{array}$ & $\begin{array}{l}\text { Raman } \\
\text { intens. }\end{array}$ & $\begin{array}{l}\text { Raman } \\
\text { scattering } \\
\text { activities }\end{array}$ & $\operatorname{PED}(\%)$ \\
\hline 87 & $\mathrm{OH}$ stretching (A) & & & 3832 & 3783 & 19 & 3 & 228 & vOH (100) \\
\hline 86 & OH stretching (B) & & & 3830 & 3781 & 23 & 3 & 285 & $v O H(100)$ \\
\hline 85 & $\mathrm{OH}$ stretching $(\mathrm{C})$ & & & 3619 & 3573 & 26 & 2 & 191 & $v \mathrm{OH}(100)$ \\
\hline 84 & $\mathrm{OH}$ stretching $(\mathrm{A})$ & 3420 vs & & 3383 & 3340 & 60 & 2 & 126 & vOH(99) \\
\hline 83 & $\mathrm{CH}$ stretching (B) & $3206 \mathrm{~s}$ & & 3243 & 3202 & 1 & 0 & 30 & $v \mathrm{CH}(99)$ \\
\hline 82 & $\mathrm{CH}$ stretching (A) & & & 3223 & 3182 & 0 & 1 & 71 & $v \mathrm{CH}(100)$ \\
\hline 81 & $\mathrm{CH}$ stretching (B) & & & 3218 & 3177 & 0 & 1 & 57 & $v \mathrm{CH}(91)$ \\
\hline 80 & $\mathrm{CH}$ stretching (B) & & & 3191 & 3151 & 1 & 2 & 129 & $v \mathrm{CH}(91)$ \\
\hline 79 & $\mathrm{CH}$ stretching $(\mathrm{A})$ & & & 3181 & 3140 & 1 & 3 & 192 & $v \mathrm{CH}(100)$ \\
\hline 78 & CH stretching (B) & & & 3155 & 3115 & 4 & 3 & 165 & vCH(99) \\
\hline 77 & $\begin{array}{l}\mathrm{C}=\mathrm{O} \text { stretching }(\mathrm{C}) \\
\mathrm{C} 2=\mathrm{C} 3 \text { stretching }(\mathrm{C}) \\
\mathrm{CC} \text { stretching }(\mathrm{A}, \mathrm{C})\end{array}$ & 1660 vs & & 1685 & 1663 & 76 & 24 & 563 & $v \mathrm{CO}(30)+v \mathrm{CC}(20)$ \\
\hline 76 & $\mathrm{C}=\mathrm{C}$ stretching $(\mathrm{B}, \mathrm{C})$ & & $1642 \mathrm{~m}$ & 1661 & 1640 & 13 & 8 & 191 & $v \mathrm{CC}(63)$ \\
\hline 75 & $\begin{array}{l}\text { CC stretching }(\mathrm{B}, \mathrm{C}) \\
\mathrm{HCC} \text { bending }(\mathrm{B}) \\
\mathrm{C}=\mathrm{O} \text { stretching }(\mathrm{C})\end{array}$ & & & 1647 & 1626 & 46 & 100 & 2276 & $\begin{array}{l}v \mathrm{CC}(50)+\delta \mathrm{HCC}(11) \\
+v \mathrm{CO}(10)\end{array}$ \\
\hline 74 & $\begin{array}{l}\mathrm{C}=\mathrm{O} \text { stretching }(\mathrm{C}) \\
\mathrm{CC} \text { stretching }(\mathrm{A}, \mathrm{C})\end{array}$ & 1612 vs & 1604 vs & 1631 & 1610 & 100 & 6 & 130 & $v \mathrm{CO}(49)+v \mathrm{CC}(12)$ \\
\hline 73 & CC stretching (B) & & & 1617 & 1596 & 0 & 0 & 5 & $v \mathrm{CC}(63)$ \\
\hline 72 & $\begin{array}{l}\mathrm{C} 2=\mathrm{C} 3 \text { stretching }(\mathrm{C}) \\
\mathrm{CC} \text { stretching }(\mathrm{A}, \mathrm{C}) \\
\mathrm{C}=\mathrm{O} \text { stretching }(\mathrm{C})\end{array}$ & $1568 \mathrm{~m}$ & $1561 \mathrm{~m}$ & 1596 & 1576 & 26 & 35 & 762 & $v \mathrm{CC}(50)+v \mathrm{CO}(14)$ \\
\hline 71 & $\begin{array}{l}\text { HCC bending (B) } \\
\text { HOC bending (B,C) }\end{array}$ & & & 1545 & 1526 & 20 & 7 & 137 & $\delta \mathrm{HCC}(25)+\delta \mathrm{HOC}(24)$ \\
\hline 70 & CC stretching $(\mathrm{A}, \mathrm{C})$ & $1509 \mathrm{~s}$ & $1509 \mathrm{w}$ & 1530 & 1511 & 64 & 5 & 108 & $\begin{array}{l}\nu \mathrm{CC}(12)+\delta \mathrm{CCO}(11) \\
+\delta \mathrm{HOC}(10)+\delta \mathrm{HCC}(10) \\
+\delta \mathrm{CCC}(10)\end{array}$ \\
\hline 69 & $\begin{array}{l}\text { CC stretching }(\mathrm{A}, \mathrm{C}) \\
\mathrm{HCC} \text { bending }(\mathrm{A}) \\
\mathrm{HOC} \text { bending }(\mathrm{A}, \mathrm{C}) \\
\mathrm{C}=\mathrm{O} \text { stretching }(\mathrm{C})\end{array}$ & & & 1506 & 1487 & 38 & 5 & 92 & $v \mathrm{CC}(40)+v \mathrm{CO}(12)$ \\
\hline 68 & $\begin{array}{l}\mathrm{CC} \text { stretching }(\mathrm{A}, \mathrm{C}) \\
\mathrm{COH} \text { bending }(\mathrm{A}) \\
\mathrm{CCH} \text { bending }(\mathrm{A}) \\
\mathrm{CO} \text { stretching }(\mathrm{C})\end{array}$ & $1456 \mathrm{vw}$ & & 1470 & 1452 & 15 & 15 & 293 & $\begin{array}{l}v \mathrm{CC}(28)+\delta \mathrm{HCC}(20) \\
+\delta \mathrm{HOC}(17)\end{array}$ \\
\hline 67 & $\begin{array}{l}\mathrm{CC} \text { stretching }(\mathrm{A}, \mathrm{C}) \\
\mathrm{COH} \text { bending }(\mathrm{A}, \mathrm{C}) \\
\mathrm{CCH} \text { bending }(\mathrm{A}) \\
\mathrm{CO} \text { stretching }(\mathrm{C}) \\
\end{array}$ & $1440 \mathrm{vw}$ & $1422 \mathrm{w}$ & 1452 & 1434 & 7 & 13 & 243 & $\begin{array}{l}v C C(10)+\delta H C C(10) \\
+\delta H O C(10)\end{array}$ \\
\hline 66 & $\begin{array}{l}\text { CC stretching }(A) \\
\text { HOC bending }(A, B, C) \\
\text { HCC bending }(A, B)\end{array}$ & & & 1424 & 1405 & 13 & 9 & 174 & $\begin{array}{l}v \mathrm{CC}(40)+\delta \mathrm{HOC}(14) \\
+\delta \mathrm{HCC}(10)\end{array}$ \\
\hline 65 & $\begin{array}{l}\text { CC stretching }(\mathrm{A}, \mathrm{C}) \\
\mathrm{CO} \text { stretching }(\mathrm{C}) \\
\mathrm{COH} \text { bending }(\mathrm{A}, \mathrm{C})\end{array}$ & $1382 \mathrm{~s}$ & & 1396 & 1378 & 28 & 3 & 49 & $\begin{array}{l}v \mathrm{CO}(17)+v \mathrm{CC}(17) \\
+\delta \mathrm{CCC}(11)\end{array}$ \\
\hline 64 & $\begin{array}{l}\text { CC stretching (A,C) } \\
\text { CO stretching (A,C) } \\
\text { COH bending (B) } \\
\text { CCH bending (B) }\end{array}$ & & $1366 \mathrm{w}$ & 1376 & 1358 & 2 & 1 & 17 & $\begin{array}{l}\delta \mathrm{HCC}(48)+\delta \mathrm{HOC}(12) \\
+v C C(21)\end{array}$ \\
\hline 63 & $\begin{array}{l}\text { CO stretching }(\mathrm{A}, \mathrm{C}) \\
\text { HOC bending }(\mathrm{A}, \mathrm{C}) \\
\text { HCC bending }(\mathrm{A}, \mathrm{B}) \\
\text { CC stretching }(\mathrm{A})\end{array}$ & & & 1351 & 1333 & 27 & 8 & 137 & $v \mathrm{CO}(35)+v \mathrm{CC}(25)$ \\
\hline
\end{tabular}


Table 3 continuation

\begin{tabular}{|c|c|c|c|c|c|c|c|c|c|}
\hline 62 & $\begin{array}{l}\text { CC stretching }(\mathrm{A}, \mathrm{C}) \\
\mathrm{CO} \text { stretching }(\mathrm{A}, \mathrm{C}) \\
\mathrm{COH} \text { bending }(\mathrm{C}, \mathrm{B})\end{array}$ & $1316 \mathrm{~m}$ & & 1343 & 1326 & 57 & 43 & 747 & $\begin{array}{l}v \mathrm{CC}(21)+\delta \mathrm{HOC}(18) \\
+v \mathrm{CO}(10)\end{array}$ \\
\hline 61 & $\begin{array}{l}\text { CO stretching }(\mathrm{A}, \mathrm{B}, \mathrm{C}) \\
\text { HOC bending }(\mathrm{A}, \mathrm{B}, \mathrm{C}) \\
\text { HCC bending }(\mathrm{B}) \\
\text { CCC bending }(\mathrm{C}, \mathrm{B})\end{array}$ & $1306 \mathrm{~m}$ & $1316 \mathrm{w}$ & 1332 & 1315 & 10 & 0 & 7 & $\begin{array}{l}v \mathrm{CC}(40)+\delta \mathrm{HCC}(19) \\
+v \mathrm{CO}(11)\end{array}$ \\
\hline 60 & $\begin{array}{l}\text { CC stretching (B) } \\
\text { CO stretching (A,C) } \\
\text { HOC bending (B) } \\
\text { HCC bending (B) }\end{array}$ & $1275 \mathrm{vw}$ & $1277 \mathrm{w}$ & 1295 & 1278 & 27 & 4 & 71 & $\begin{array}{l}v \mathrm{CO}(35)+\delta \mathrm{HCC}(17) \\
+v \mathrm{CC}(16)\end{array}$ \\
\hline 59 & $\begin{array}{l}\text { CO stretching }(\mathrm{A}, \mathrm{C}) \\
\mathrm{CC} \text { stretching }(\mathrm{A})\end{array}$ & & & 1281 & 1264 & 32 & 1 & 22 & $v \mathrm{CO}(25)+v \mathrm{CC}(24)$ \\
\hline 58 & $\begin{array}{l}\text { CC stretching (A,C) } \\
\text { CO stretching (A,C) } \\
\text { HOC bending (A) } \\
\text { HCC bending (A) } \\
\text { COC bending (C) }\end{array}$ & $1252 \mathrm{~m}$ & & 1259 & 1243 & 8 & 1 & 15 & $\begin{array}{l}v \mathrm{CO}(22)+\delta \mathrm{HCC}(20) \\
+\delta \mathrm{HOC}(20)\end{array}$ \\
\hline 57 & $\begin{array}{l}\text { HCC bending }(A, B) \\
\text { CCC bending }(A, B, C) \\
\text { HOC bending }(C) \\
\text { CCO bending }(C) \\
\text { COC bending }(C)\end{array}$ & $1223 \mathrm{~m}$ & $1222 \mathrm{w}$ & 1227 & 1211 & 32 & 0 & 3 & $v \mathrm{CO}(37)+\delta \mathrm{HCC}(10)$ \\
\hline 56 & $\begin{array}{l}\text { CO stretching }(\mathrm{C}) \\
\text { HOC bending }(\mathrm{A}, \mathrm{B}, \mathrm{C}) \\
\text { HCC bending }(\mathrm{A}, \mathrm{B})\end{array}$ & & & 1210 & 1195 & 18 & 17 & 263 & $\delta \mathrm{HCC}(48)+v \mathrm{CO}(24)$ \\
\hline 55 & $\begin{array}{l}\text { CCO bending }(\mathrm{A}, \mathrm{C}) \\
\mathrm{COH} \text { bending }(\mathrm{A}, \mathrm{C}) \\
\mathrm{HCC} \text { bending }(\mathrm{A})\end{array}$ & & $1185 \mathrm{~m}$ & 1197 & 1182 & 9 & 2 & 29 & $\begin{array}{l}v \mathrm{CO}(25)+\delta \mathrm{HCC}(14) \\
+\delta \mathrm{HOC}(13)\end{array}$ \\
\hline 54 & $\begin{array}{l}\text { HOC bending }(\mathrm{A}, \mathrm{B}) \\
\text { HCC bending }(\mathrm{B})\end{array}$ & & & 1189 & 1174 & 46 & 5 & 77 & $\delta \mathrm{HOC}(40)+\delta \mathrm{HCC}(30)$ \\
\hline 53 & $\begin{array}{l}\mathrm{COH} \text { bending }(\mathrm{A}) \\
\mathrm{CCH} \text { bending }(\mathrm{A})\end{array}$ & 1177 vs & & 1176 & 1161 & 74 & 2 & 24 & $\delta \mathrm{HCC}(25)+\delta \mathrm{HOC}(23)$ \\
\hline 52 & $\begin{array}{l}\mathrm{CCH} \text { bending }(\mathrm{A}, \mathrm{B}) \\
\mathrm{COH} \text { bending }(\mathrm{C}, \mathrm{B})\end{array}$ & & & 1152 & 1137 & 3 & 1 & 11 & $\begin{array}{l}v \mathrm{CO}(38)+\delta \mathrm{HOC}(16) \\
+\delta \mathrm{HCC}(15)\end{array}$ \\
\hline 51 & $\begin{array}{l}\mathrm{COH} \text { bending }(\mathrm{A}, \mathrm{B}, \mathrm{C}) \\
\mathrm{CCH} \text { bending }(\mathrm{A}, \mathrm{B})\end{array}$ & $1129 \mathrm{vw}$ & $\begin{array}{l}1117 \\
\text { vw }\end{array}$ & 1138 & 1123 & 9 & 1 & 9 & $\begin{array}{l}\mathrm{vCO}(20)+ \\
\delta \mathrm{HCC}(13)+\delta \mathrm{HOC}(11) \\
+\delta \mathrm{CCC}(10)\end{array}$ \\
\hline 50 & $\begin{array}{l}\text { CCH bending }(\mathrm{A}, \mathrm{B}) \\
\mathrm{COH} \text { bending }(\mathrm{A}, \mathrm{C}) \\
\mathrm{COC} \text { bending }(\mathrm{C}) \\
\mathrm{CCC} \text { bending }(\mathrm{A}, \mathrm{B}, \mathrm{C})\end{array}$ & $1090 \mathrm{w}$ & $\begin{array}{l}1090 \\
\text { vw }\end{array}$ & 1103 & 1089 & 4 & 1 & 16 & $\begin{array}{l}v \mathrm{CO}(30)+ \\
\delta \mathrm{HCC}(14)+\delta \mathrm{HOC}(10) \\
+\delta \mathrm{CCC}(10)\end{array}$ \\
\hline 49 & $\begin{array}{l}\text { HCC bending (A,B) } \\
\text { CCC bending (B) }\end{array}$ & & & 1030 & 1017 & 2 & 1 & 7 & $\delta \mathrm{HCC}(43)+\delta \mathrm{CCC}(42)$ \\
\hline 48 & $\begin{array}{l}\mathrm{CCH} \text { bending }(\mathrm{A}) \\
\mathrm{COH} \text { bending }(\mathrm{A}, \mathrm{C})\end{array}$ & $1008 \mathrm{w}$ & $\begin{array}{l}1008 \\
\text { vw }\end{array}$ & 1023 & 1010 & 4 & 0 & 5 & $v \mathrm{CO}(45)+\delta \mathrm{HCC}(42)$ \\
\hline 47 & $\begin{array}{l}\mathrm{CCH} \text { bending }(\mathrm{A}) \\
\mathrm{COH} \text { bending }(\mathrm{A}, \mathrm{C})\end{array}$ & $974 \mathrm{w}$ & $976 \mathrm{vw}$ & 991 & 978 & 6 & 4 & 50 & $\begin{array}{l}v \mathrm{CO}(40)+\delta \mathrm{HCC}(15) \\
+\delta \mathrm{CCC}(11)\end{array}$ \\
\hline 46 & HCCC torsion (B) & & & 985 & 972 & 0 & 0 & 0 & $\tau \mathrm{HCCC}(90)$ \\
\hline 45 & HCCC torsion (B) & & & 965 & 953 & 0 & 0 & 0 & $\tau \mathrm{HCCC}(90)$ \\
\hline 44 & $\begin{array}{l}\text { CCC bending }(\mathrm{A}, \mathrm{B}, \mathrm{C}) \\
\mathrm{CCO} \text { bending }(\mathrm{A}, \mathrm{C}) \\
\mathrm{COH} \text { bending }(\mathrm{A}, \mathrm{B}, \mathrm{C}) \\
\mathrm{CCH} \text { bending }(\mathrm{A}, \mathrm{B}) \\
\end{array}$ & & $882 \mathrm{vw}$ & 892 & 881 & 3 & 0 & 3 & $\begin{array}{l}\delta \mathrm{HCC}(14)+\delta \mathrm{CCC}(14)+ \\
\delta \mathrm{COC}(11)+\delta \mathrm{CCO}(11)+ \\
\delta \mathrm{HOC}(10)\end{array}$ \\
\hline 43 & HCCC torsion (B) & & & 850 & 839 & 9 & 0 & 0 & $\tau \mathrm{HCCC}(90)$ \\
\hline 42 & $\begin{array}{l}\mathrm{CCO} \text { bending }(\mathrm{A}, \mathrm{B}, \mathrm{C}) \\
\mathrm{COH} \text { bending }(\mathrm{B}) \\
\mathrm{CCC} \text { bending }(\mathrm{B}) \\
\mathrm{CCH} \text { bending }(\mathrm{A}, \mathrm{B})\end{array}$ & & $828 \mathrm{vw}$ & 834 & 823 & 3 & 8 & 77 & $\begin{array}{l}v \mathrm{CO}(24)+\delta \mathrm{CCC}(20) \\
+\delta \mathrm{CCO}(18)\end{array}$ \\
\hline 41 & $\begin{array}{l}\text { HCCC torsion (A) } \\
\text { HOCC torsion (A) }\end{array}$ & & & 826 & 816 & 0 & 0 & 0 & $\tau \mathrm{HCCC}(50)+\tau \mathrm{HOCC}(40)$ \\
\hline 40 & HCCC torsion $(\mathrm{A}, \mathrm{B})$ & & & 820 & 809 & 0 & 0 & 0 & $\tau \mathrm{HCCC}(93)$ \\
\hline 39 & $\begin{array}{l}\text { HCCC torsion }(A, B) \\
\text { HOCC torsion }(A)\end{array}$ & & & 818 & 808 & 7 & 0 & 0 & $\tau \mathrm{HCCC}(45)+\tau \mathrm{HOCC}(37)$ \\
\hline 38 & HOCC torsion (A) & & & 776 & 766 & 22 & 0 & 1 & $\tau \mathrm{tHOCC}(79)$ \\
\hline
\end{tabular}


Table 3 continuation

\begin{tabular}{|c|c|c|c|c|c|c|c|c|c|}
\hline 37 & $\begin{array}{l}\text { HCCC torsion }(\mathrm{A}, \mathrm{B}) \\
\text { HOCC torsion }(\mathrm{A}) \\
\text { OCCC torsion (C) o.p. } \\
\text { CCCC torsion }(\mathrm{C}, \mathrm{B})\end{array}$ & & $725 \mathrm{vw}$ & 728 & 718 & 0 & 0 & 3 & $\begin{array}{l}\tau \mathrm{HCCC}(26)+\tau \mathrm{HOCC}(20) \\
+\gamma \mathrm{OCCC}(15) \\
+\tau \mathrm{CCCC}(10)\end{array}$ \\
\hline 36 & $\begin{array}{l}\text { HCCC torsion }(\mathrm{A}, \mathrm{B}) \\
\text { HOCC torsion }(\mathrm{A}) \\
\text { OCCC torsion }(\mathrm{C}) \text { o.p. } \\
\text { CCCC torsion }(\mathrm{C}, \mathrm{B})\end{array}$ & & & 726 & 717 & 0 & 0 & 2 & $\begin{array}{l}\tau \mathrm{HCCC}(28)+\tau \mathrm{HOCC}(23) \\
+\gamma \mathrm{OCCC}(15) \\
+\tau \mathrm{CCCC}(15)\end{array}$ \\
\hline 35 & $\begin{array}{l}\text { CCO bending }(\mathrm{A}, \mathrm{C}) \\
\mathrm{CCC} \text { bending }(\mathrm{A}, \mathrm{B}, \mathrm{C}) \\
\mathrm{COC} \text { bending }(\mathrm{C}) \\
\mathrm{HCC} \text { bending }(\mathrm{A}, \mathrm{B})\end{array}$ & & & 722 & 713 & 0 & 0 & 1 & $\begin{array}{l}\delta \mathrm{CCO}(17)+\delta \mathrm{CCC}(15) \\
+\delta \mathrm{COC}(14)+\delta \mathrm{HCC}(12)\end{array}$ \\
\hline 34 & $\begin{array}{l}\text { CCO bending }(\mathrm{A}, \mathrm{B}, \mathrm{C}) \\
\text { COC bending }(\mathrm{C}) \\
\text { CCC bending }(\mathrm{A}, \mathrm{B}, \mathrm{C})\end{array}$ & $702 \mathrm{vw}$ & $690 \mathrm{w}$ & 692 & 683 & 2 & 2 & 14 & $\begin{array}{l}\delta \mathrm{CCC}(18)+\delta \mathrm{CCO}(15) \\
+\delta \mathrm{HCC}(10)\end{array}$ \\
\hline 33 & $\begin{array}{l}\text { HCCC torsion (A,B) } \\
\text { CCCC torsion (A) } \\
\text { HOCC torsion (A) }\end{array}$ & & & 679 & 670 & 0 & 0 & 0 & $\begin{array}{l}\tau \mathrm{HCCC}(35)+\tau \mathrm{CCCC}(28) \\
+\tau \mathrm{HOCC}(24)\end{array}$ \\
\hline 32 & $\begin{array}{l}\text { CCC bending (B) } \\
\text { HCC bending (B) }\end{array}$ & & & 653 & 645 & 0 & 1 & 6 & $\delta \mathrm{CCC}(60)+\delta \mathrm{HCC}(27)$ \\
\hline 31 & $\begin{array}{l}\text { CCO bending }(\mathrm{A}) \\
\mathrm{CCC} \text { bending }(\mathrm{A}, \mathrm{B}, \mathrm{C}) \\
\mathrm{COC} \text { bending }(\mathrm{C})\end{array}$ & $639 \mathrm{vw}$ & $637 \mathrm{w}$ & 644 & 636 & 3 & 3 & 20 & $\begin{array}{l}\delta \mathrm{CCC}(15)+\delta \mathrm{CCO}(14)+ \\
\delta \mathrm{HCC}(14)\end{array}$ \\
\hline 30 & CCO bending (B) & $620 \mathrm{vw}$ & & 640 & 632 & 1 & 0 & 2 & $\begin{array}{l}\tau \mathrm{HCCC}(17)+\tau \mathrm{CCOC}(18) \\
+\tau \mathrm{CCCC}(17)\end{array}$ \\
\hline 29 & $\begin{array}{l}\text { HCCC torsion }(\mathrm{A}, \mathrm{B}) \\
\text { HOCC torsion }(\mathrm{A}, \mathrm{C}) \\
\text { COCC torsion }(\mathrm{C}) \\
\text { CCCC torsion }(\mathrm{B}, \mathrm{C})\end{array}$ & & & 626 & 618 & 0 & 0 & 1 & $\begin{array}{l}\tau \mathrm{HCCC}(23)+\tau \mathrm{HOCC}(20) \\
+\tau \mathrm{COCC}(19) \\
+\tau \mathrm{CCCC}(14)\end{array}$ \\
\hline 28 & $\begin{array}{l}\text { HCCC torsion }(\mathrm{A}, \mathrm{B}) \\
\text { HOCC torsion }(\mathrm{A}, \mathrm{C}) \\
\text { CCCO torsion }(\mathrm{A})\end{array}$ & & & 603 & 596 & 1 & 0 & 0 & $\begin{array}{l}\tau \mathrm{HCCC}(30)+\tau \mathrm{HOCC}(25) \\
+\tau \mathrm{CCCO}(20)\end{array}$ \\
\hline 27 & $\begin{array}{l}\text { CCOH torsion }(\mathrm{A}, \mathrm{B}) \\
\mathrm{CCCO} \text { torsion }(\mathrm{A}, \mathrm{B}, \mathrm{C}) \\
\mathrm{CCOC} \text { torsion }(\mathrm{C}) \\
\mathrm{CCCC} \text { torsion }(\mathrm{B})\end{array}$ & $584 \mathrm{vw}$ & $578 \mathrm{vw}$ & 589 & 582 & 3 & 7 & 45 & $\begin{array}{l}\delta \mathrm{CCC}(15)+\delta \mathrm{CCO}(13)+ \\
\delta \mathrm{HCC}(12) \\
+\delta \mathrm{HOC}(12)+v \mathrm{CO}(10)\end{array}$ \\
\hline 26 & $\begin{array}{l}\text { CCOH torsion }(\mathrm{A}, \mathrm{B}, \mathrm{C}) \\
\mathrm{CCOC} \text { torsion }(\mathrm{C}) \\
\mathrm{CCCC} \text { torsion }(\mathrm{A}, \mathrm{B}, \mathrm{C})\end{array}$ & $565 \mathrm{vw}$ & $565 \mathrm{w}$ & 572 & 565 & 5 & 1 & 7 & $\begin{array}{l}\delta \mathrm{CCO}(20)+\delta \mathrm{HCC}(17) \\
+\delta \mathrm{HOC}(17)+\delta \mathrm{CCC}(14)\end{array}$ \\
\hline 25 & $\begin{array}{l}\text { CCCH torsion (A) } \\
\text { CCCC torsion (A) } \\
\text { CCOH torsion (A) } \\
\text { HCCO torsion (A,C) }\end{array}$ & & $516 \mathrm{vw}$ & 528 & 521 & 2 & 2 & 13 & $\begin{array}{l}\delta \mathrm{CCO}(20)+\delta \mathrm{CCC}(17) \\
+\delta \mathrm{HCC}(15)+\delta \mathrm{HOC}(15) \\
+\delta \mathrm{COC}(12)\end{array}$ \\
\hline 24 & $\begin{array}{l}\text { HOCC torsion }(B, C) \\
\text { HCCC torsion }(B)\end{array}$ & & & 502 & 496 & 1 & 0 & 1 & $\tau \mathrm{HOCC}(44)+\tau \mathrm{HCCC}(33)$ \\
\hline 23 & $\begin{array}{l}\mathrm{CCCH} \text { torsion }(\mathrm{A}, \mathrm{B}) \\
\mathrm{CCCC} \text { torsion }(\mathrm{A}, \mathrm{C}) \\
\mathrm{CCOH} \text { torsion }(\mathrm{A}) \\
\mathrm{HCCO} \text { torsion }(\mathrm{A}, \mathrm{C}) \\
\end{array}$ & & $460 \mathrm{vw}$ & 462 & 456 & 0 & 1 & 5 & $\begin{array}{l}\delta \mathrm{CCO}(17)+\delta \mathrm{CCC}(16) \\
+\delta \mathrm{HCC}(14)+\delta \mathrm{HOC}(13) \\
+\delta \mathrm{COC}(11)\end{array}$ \\
\hline
\end{tabular}

The high-frequency region is characteristic of $\mathrm{C}-\mathrm{H}$ stretching modes of the $\mathrm{A}$ and $\mathrm{B}$ rings as well. In the $4000-3000 \mathrm{~cm}^{-1}$ Raman region (Figure S2) there are no bands easily assignable to the $\mathrm{O}-\mathrm{H}$ and $\mathrm{C}-\mathrm{H}$ stretching modes. The vibrational contributions to the normal modes (PED values in Table 3 ) in the $3780-3115 \mathrm{~cm}^{-1}$ region are assigned solely to the $\mathrm{O}-\mathrm{H}$ and $\mathrm{C}-\mathrm{H}$ stretching modes themselves (91-100\%). The remaining modes are presented as combinations of the various contributions.

The majority of the medium-to-strongintensity bands in both IR and Raman spectra of kaempferol are to be found in the $1800-1500 \mathrm{~cm}^{-1}$ region (Figs. 4 and 5, Table 3). This region in- volves combinations of the $\mathrm{C}=\mathrm{O}$ stretching $\left(1660_{(\mathrm{IR})}, 1612_{(\mathrm{IR})}\right.$ and $1604_{(\mathrm{R})} \mathrm{cm}^{-1}$; modes $v_{77}$ and $\left.v_{74}\right), \mathrm{C} 2=\mathrm{C} 3$ stretching $\left(1660_{(\mathrm{IR})}\right.$ and $1568_{(\mathrm{IR})} \mathrm{cm}^{-1}$ and $1561_{(\mathrm{R})} \mathrm{cm}^{-1}$; modes $v_{77}$ and $\left.v_{72}\right)$ and $\mathrm{C}-\mathrm{C}$ stretching $\left(1660_{(\mathrm{IR})}, 1612_{(\mathrm{IR})}, 1568_{(\mathrm{IR})}, 1509_{(\mathrm{IR})} \mathrm{cm}^{-1}\right.$, $1642_{(\mathrm{R})}, 1604_{(\mathrm{R})}, 561_{(\mathrm{R})}$ and $1509_{(\mathrm{R})} \mathrm{cm}^{-1}$; modes $v_{77}$, $v_{74}, v_{72}$ and $v_{70}$ ) modes.

In the region between 1500 and $1000 \mathrm{~cm}^{-1}$, bands mostly involve $\mathrm{C}-\mathrm{C}$ stretching, $\mathrm{O}-\mathrm{C}$ stretching and in-plane $\mathrm{C}-\mathrm{C}-\mathrm{H}, \mathrm{C}-\mathrm{O}-\mathrm{H}, \mathrm{C}-\mathrm{C}-\mathrm{O}$ and $\mathrm{C}-$ $\mathrm{C}-\mathrm{C}$ bending vibrations of the rings. The mediumto-strong-intensity bands in the same region belong to modes at $1382_{(\mathrm{IR})}, 1316_{(\mathrm{IR})}, 1306_{(\mathrm{IR})}, 1252_{(\mathrm{IR})}$, $1223_{(\mathrm{IR})}$ and $1185_{(\mathrm{R})} \mathrm{cm}^{-1}$ (modes $v_{65}, v_{62}, v_{61}, v_{58}$, 
$v_{57}$, and $v_{53}$, respectively) (Figs. 4 and 5, Table 3). The low- (and very low-) intensity bands observed at $1456_{(\mathbb{R})}, 1440_{(\mathrm{IR})}, 1442_{(\mathrm{R})}, 1366_{(\mathrm{IR})}, 1316_{(\mathrm{R})}$, $1275_{(\mathrm{IR})}, 1277_{(\mathrm{R})}, 1222_{(\mathrm{R})}, 1129_{(\mathrm{IR})}, 1117_{(\mathrm{R})}, 1090_{(\mathrm{IR}, \mathrm{R})}$ and $1008_{(\mathrm{IR}, \mathrm{R})}, \mathrm{cm}^{-1}$ (modes $v_{68}, v_{67}, v_{64}, v_{61}, v_{60}$, $v_{57}, v_{51}, v_{50}$ and $\left.v_{48}\right)$ are also assigned to the different stretching $(\mathrm{C}-\mathrm{C}, \mathrm{O}-\mathrm{C})$ and bending $(\mathrm{C}-\mathrm{C}-\mathrm{H}$, $\mathrm{C}-\mathrm{O}-\mathrm{H}, \mathrm{C}-\mathrm{C}-\mathrm{O}, \mathrm{C}-\mathrm{C}-\mathrm{C})$ modes of the rings.

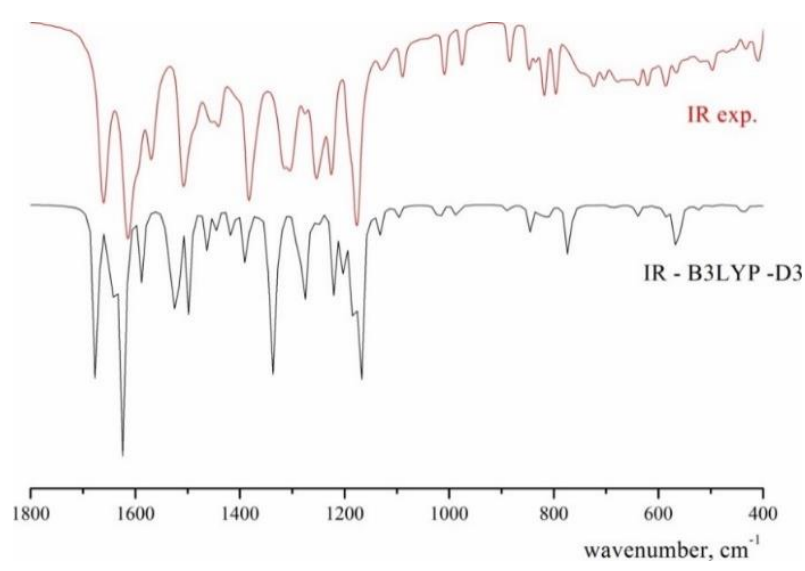

Fig. 4. The $1800-400 \mathrm{~cm}^{-1}$ IR regions of the experimental and theoretical spectra of kaempferol

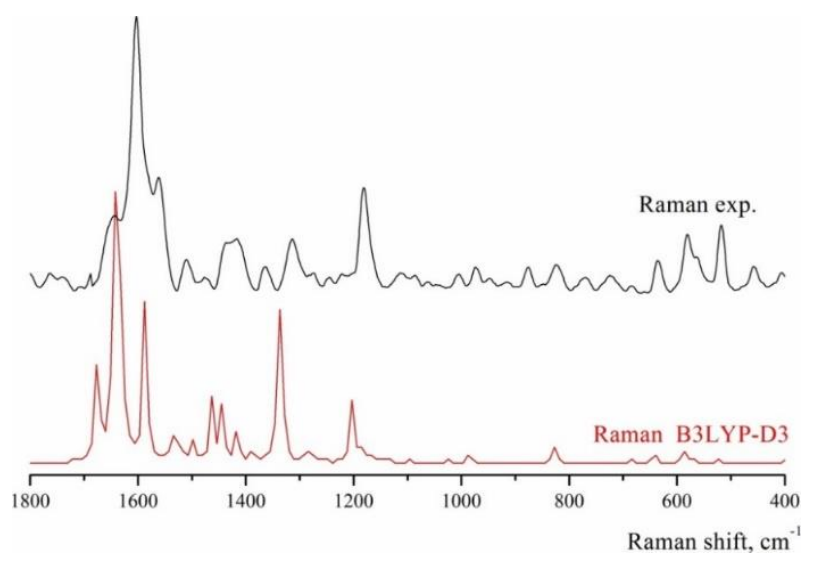

Fig. 5. The $1800-400 \mathrm{~cm}^{-1}$ Raman regions of the experimental and theoretical spectra of kaempferol

The linear relationship between the experimental and calculated wavelengths was proven from the data presented in Table 3 . Three descriptors: the correlation coefficient (R), the average absolute error (AAE), and the average relative error (ARE), were used to examine the quality of the linear correlation. The $\mathrm{R}$ values for the IR and Raman spectra are 0.9999 and 0.9997. The AAE and ARE values for the IR spectrum are $11 \mathrm{~cm}^{-1}$ and $1.0 \%$, while for the Raman spectrum these values are $7 \mathrm{~cm}^{-1}$ and $0.7 \%$. According to the obtained results, the B3LYP-D3 functional can be considered as giving very good agreement between the experimentally and theoretically obtained spectra.

\subsection{NMR spectra of kaempferol}

The ${ }^{13} \mathrm{C}$ and ${ }^{1} \mathrm{H}$ NMR spectra of kaempferol were measured in DMSO and used to confirm the structure of the molecule. The experimental results were compared to the theoretical values determined by the GIAO method. The scaling factor of 0.932 ( ${ }^{1} \mathrm{H}$ NMR) was determined by the leastsquares method. The experimental and theoretical positions of the peaks in the ${ }^{13} \mathrm{C}$ NMR and ${ }^{1} \mathrm{H}$ NMR spectra are given in Tables 4 and 5. The corresponding spectra are presented in Figures S3 and $\mathrm{S} 4$ (the atom numbering is in line with the designation in Fig. 1).

Table 4

Calculated and experimental ${ }^{13} \mathrm{C} \mathrm{NMR}$ chemical shifts of the selected carbons

\begin{tabular}{ccc}
\hline \hline${ }^{13} \mathrm{C}$ NMR & Experimental & Calculated \\
\hline $\mathrm{C}(2)$ & 147.0 & 146.2 \\
$\mathrm{C}(3)$ & 135.8 & 135.1 \\
$\mathrm{C}(4)$ & 176.0 & 175.1 \\
$\mathrm{C}(5)$ & 160.9 & 160.0 \\
$\mathrm{C}(6)$ & 103.2 & 102.7 \\
$\mathrm{C}(7)$ & 164.1 & 163.3 \\
$\mathrm{C}(8)$ & 93.7 & 93.2 \\
$\mathrm{C}(9)$ & 156.4 & 155.6 \\
$\mathrm{C}(10)$ & 98.4 & 97.9 \\
$\mathrm{C}\left(1^{\prime}\right)$ & 121.8 & 121.2 \\
$\mathrm{C}\left(2^{\prime}\right)$ & 129.6 & 129.0 \\
$\mathrm{C}\left(3^{\circ}\right)$ & 115.6 & 115.0 \\
$\mathrm{C}\left(4^{\prime}\right)$ & 159.3 & 158.5 \\
$\mathrm{C}\left(5^{\prime}\right)$ & 115.6 & 115.0 \\
$\mathrm{C}\left(6^{\circ}\right)$ & 129.6 & 129.0 \\
\hline Average absolute & & 0.68 \\
error (AAE) & & 0.999 \\
\hline R & & \\
\hline \hline
\end{tabular}

Table 5

Calculated and experimental ${ }^{1} H$ NMR chemical shifts of the protons bonded to carbons

\begin{tabular}{lcc}
\hline \hline${ }^{1} \mathrm{H} N M R$ & Experimental & Calculated \\
\hline $\mathrm{C}(6) \mathrm{H}$ & 6.19 & 6.21 \\
$\mathrm{C}(8) \mathrm{H}$ & 6.44 & 6.35 \\
$\mathrm{C}\left(2^{\circ}\right) \mathrm{H}$ & 8.09 & 8.37 \\
$\mathrm{C}\left(3^{\circ}\right) \mathrm{H}$ & 6.92 & 6.80 \\
$\mathrm{C}\left(5^{\circ}\right) \mathrm{H}$ & 6.92 & 6.93 \\
$\mathrm{C}\left(6^{\circ}\right) \mathrm{H}$ & 8.09 & 7.96 \\
\hline Average absolute & & 0.11 \\
error (AAE) & & 0.986 \\
\hline $\mathrm{R}$ & & \\
\hline \hline
\end{tabular}


The chemical shifts obtained experimentally are in the perfect agreement with the available literature data $(\mathrm{R}=1.0000)[42,53]$. The calculated and experimental chemical shift values given in Tables 4 and 5 show good correspondence. The correlation coefficients in Tables 4 and 5 are moderately large, while the AAEs are relatively small. According to the values of R and AAE, B3LYPD3 shows a reasonable ability to describe the NMR parameters of kaempferol.

\subsection{Molecular docking studies}

To evaluate the inhibitory nature of kaempferol against human PCT, a molecular docking investigation was performed. Protein-ligand binding energy and identification of the potential ligand binding sites were also determined from this study. The ligand conformation that showed the lowest binding energy (best position) was determined based on the ligand docking results. The position and orientation of ligand inside the protein receptor and the interactions with amino acids, which are bound to the ligand, were analyzed and visualized with Discovery Studio 4.0 and AutoDockTools.

Table S3 gives the values of the estimated free energy of binding and inhibition constants $\left(\mathrm{K}_{\mathrm{i}}\right)$, for the investigated ligand in 10 different conformations. Lower values of $\mathrm{K}_{\mathrm{i}}$ indicate better inhibition. The lowest values of $\Delta G_{\text {bind }}$ and $\mathrm{K}_{\mathrm{i}}$ are found for conformation 1 (Table S3). Based on analysis of the relative positions of the ligand and the active amino acids, it can be concluded that the ligand binds to the catalytic site of the substrate by weak non-covalent interactions. The most prominent are H-bonds and alkyl- $\pi$ interactions. ASP in position 53 in the primary structure of the PCT chain has a predominant role as the active site of human PCT regarding its inhibition action. This result stands regardless of the conformation of the investigated ligand (Fig. 6). ASP53 forms one $\mathrm{H}-$ bond $(2.27 \AA$ length) with an $\mathrm{O}-\mathrm{H}$ group of the ligand (Fig. 6). PRO55, ARG56 and LEU52 form weak alkyl- $\pi$ interactions with the benzene and chromene rings of the ligand (Fig. 6).

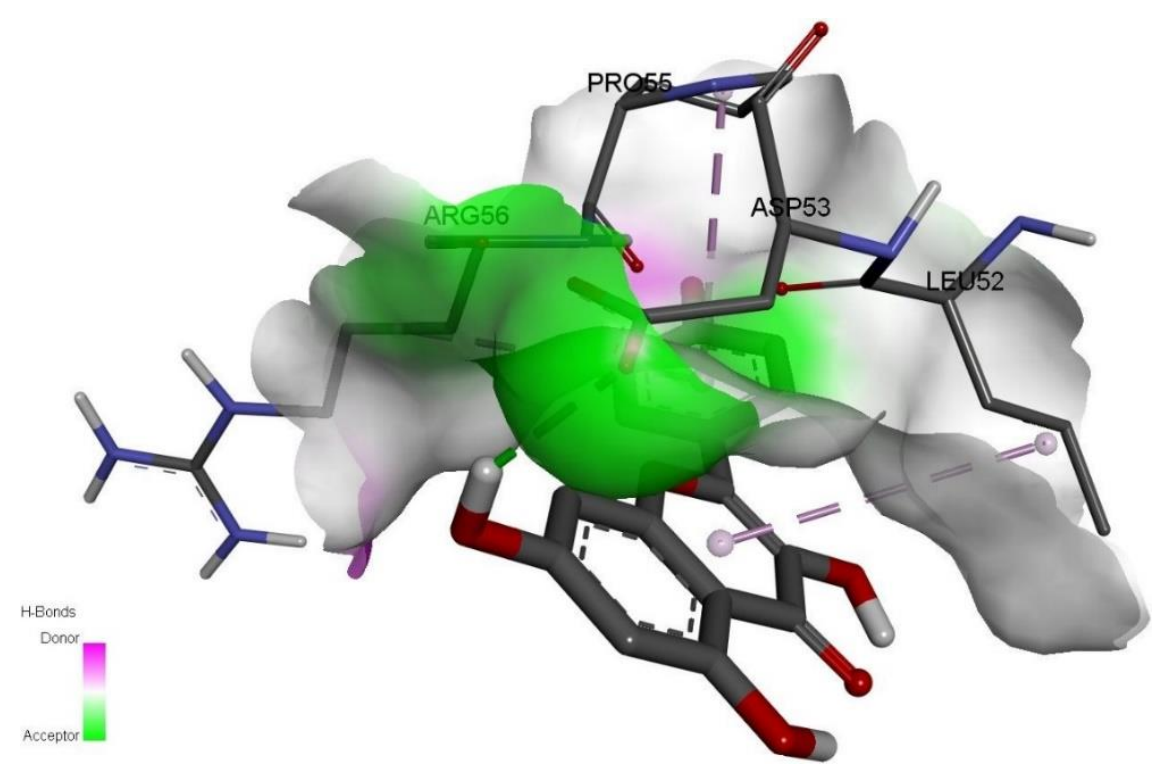

Fig. 6. Interactions between ligand (conformation 1, the lowest $\mathrm{K}_{\mathrm{i}}$ ) and amino acids in procalcitonin

\section{CONCLUSIONS}

The results of the application of the B3LYP$\mathrm{D} 3 / 6-311++\mathrm{G}(\mathrm{d}, \mathrm{p})$ density functional method in determination of the spectroscopic and electronic features of kaempferol point to a planar molecule, characterized by the facilitated electron delocalization between the $\mathrm{B}$ and $\mathrm{C}$ rings. Three IR and $\mathrm{Ra}-$ man spectra descriptors (the correlation coefficient $\mathrm{R}$, the average absolute error AAE, and the average relative error ARE) demonstrate that B3LYP-D3 provides very good agreement between the experimental and simulated vibrational spectra. Two NMR spectral descriptors ( $\mathrm{R}$ and AAE) indicate the B3LYP-D3 method as showing reasonably good results in describing the NMR spectrum of kaempferol. The calculated high polarizability value of kaempferol indicates the possibility of its tight binding to the biologically active components. The results of molecular docking study have shown that kaempferol, when acting as the ligand, can form a stable complex with human procalci- 
tonin protein, as evidenced by the binding energy value $\left(\Delta G_{\text {bind }}=-2.68 \mathrm{kcal} \mathrm{mol}^{-1}\right)$. The most important interactions are H-bonds and alkyl $-\pi$ interactions. These preliminary results suggest that kaempferol might exhibit significant inhibitory activity against PCT.

Acknowledgements. The authors acknowledge financial support by the Ministry of Education, Science and Technological Development of the Republic of Serbia (Grants No. 172015 and 172040). The authors thank Prof. Jamróz MH for the VEDA 4 software.

\section{REFERENCES}

[1] V. Cody, E. Middleton, J. B. Harborne, Plant flavonoids in biology and medicine. Biochemical, pharmacological, and structure-activity relationships. Proceedings of a symposium, Buffalo, New York, July 22-26, 1985, Prog. Clin. Biol. Res. 213, 1-592 (1986).

[2] C. Rice-Evans, Flavonoid antioxidants, Curr. Med. Chem. 8, 797-807 (2001).

DOI:10.2174/0929867013373011

[3] J. M. Calderón-Montaño, E. Burgos-Morón, C. PérezGuerrero, M. López-Lázaro, A review on the dietary flavonoid kaempferol, Mini Rev. Med. Chem. 11, 298344 (2011). DOI:10.2174/138955711795305335.

[4] S. V. Jovanovic, S. Steenken, M. Tosic, B. Marjanovic, M. G. Simic, Flavonoids as antioxidants, J. Am. Chem. Soc. 116, 4846-4851 (1994). DOI:10.1021/ja00090a032.

[5] P. G. Pietta, Flavonoids as antioxidants, J. Nat. Prod. 63, 1035-1042 (2000). DOI:10.1021/np9904509.

[6] A. Marfak, P. Trouillas, D. P. Allais, Y. Champavier, C. A. Calliste, J. L. Duroux, Radiolysis of kaempferol in water/methanol mixtures. Evaluation of antioxidant activity of kaempferol and products formed, J. Agric. Food Chem. 51, 1270-1277 (2003). DOI:10.1021/jf020836g.

[7] T. Walle, Absorption and metabolism of flavonoids, Free Rad. Biol. Med. 36, 829-837 (2004). DOI:10.1016/j.freeradbiomed.2004.01.002.

[8] R. J. Williams, J. P. E. Spencer, C. Rice-Evans, Flavonoids: antioxidants or signalling molecules? Free Rad. Biol. Med. 36, 838-849 (2004). DOI:10.1016/j.freeradbiomed.2004.01.001.

[9] C. G. Fraga, M. Galleano, S. V. Verstraeten, P. I. Oteiza, Basic biochemical mechanisms behind the health benefits of polyphenols, Mol. Aspects Med. 31, 435-445 (2010). DOI:10.1016/j.mam.2010.09.006.

[10] R. M. Han, J. P. Zhang, L. H. Skibsted, Reaction dynamics of flavonoids and carotenoids as antioxidants, Molecules 17, 2140-2160 (2012). DOI:10.3390/molecules 17022140.

[11] D. Pal, P. Verma, Flavonoids: a powerful and abundant source of antioxidants, Int. J. Pharm. Pharm. Sci. 5, 9598 (2013).

[12] D. Procházková, I. Boušová, N. Wilhelmová, Antioxidant and prooxidant properties of flavonoids, Fitoterapia 82, 513-523 (2011). DOI:10.1016/j.fitote.2011.01.018.

[13] J. B. Harborne, H. Baxter, The Handbook of Natural Flavonoids, John Wiley \& Sons, Chichester, New York, 1999.
[14] J. Heilmann, I. Merfort, M. Weiss, Radical scavenger activity of different 3',4'-dihydroxyflavonols and 1,5dicaffeoylquinic acid studied by inhibition of chemiluminescence, Planta Med. 61, 435-438 (1995). DOI:10.1055/s-2006-958131.

[15] A. Galano, G. Mazzone, R. Alvarez-Diduk, T. Marino, J. R. Alvarez-IdaboyR, N. Russo, Food antioxidants: chemical insights at the molecular level, Annu. Rev. Food Sci. Technol. 7, 335-352 (2016). DOI:10.1146/annurev-food-041715-033206.

[16] M. Leopoldini, N. Russo, M. Toscano, The molecular basis of working mechanism of natural polyphenolic antioxidants, Food Chem. 125, 288-306 (2011). DOI:10.1016/j.foodchem.2010.08.012.

[17] Ø. M. Andersen, K. R. Markham, Flavonoids: Chemistry, Biochemistry and Applications, Taylor and Francis, Boca Raton, New York, 2006.

[18] P. Rajendran, T. Rengarajan, N. Nandakumar, R. Palaniswami, Y. Nishigaki, I. Nishigaki, Kaempferol, a potential cytostatic and cure for inflammatory disorders, Eur. J. Med. Chem. 86, 103-112 (2014). DOI:10.1016/j.ejmech.2014.08.011.

[19] U. Çoruh, R. Ustabaş, H. Türker Akçay, E. Menteşe, E. M. Vazquez Lopez, Experimental and theoretical studies of 4-[(4-methyl-5-phenyl-4H1,2,4-triazol-3-zl)sulfanyl] benzene-1,2-dicarbonitrile, Maced. J. Chem. Chem. Eng. 35, 165-177 (2016). DOI: $10.20450 /$ mjcce. 2016.836 .

[20] M. A. Al-Alshaikh, S. Muthu, E. S. Al-Abdullah, E. E. Porchelvi, S. Lahsasni, A. A. El-Emam, Structural and spectroscopic characterization of $\mathrm{N}^{\prime}-[(1 E)-(4-$ fluorophenyl)methylidene]thiophene-2-carbohydrayide, Maced. J. Chem. Chem. Eng. 35, 63-77 (2016). DOI:10.20450/mjcce.2016.811.

[21] R. Álvarez-Diduk, M. T. Ramírez-Silva, A. Galano, A. Merkoçi, Deprotonation mechanism and acidity constants in aqueous solution of flavonols: a combined experimental and theoretical study, J. Phys. Chem. B 117, 12347-12359 (2013). DOI:10.1021/jp4049617.

[22] W. Weglöhner, J. Struck, C. Fischer-Schulz, N. G. Morgenthaler, A. Otto, C. Bohuon, A. Bergmann, Isolation and characterization of serum procalcitonin from patients with sepsis, Peptides 22, 2099-2103 (2001).

[23] E. S. Nylén, R. H. Snider Jr, K. A. Thompson, P. Rohatgi, K. L. Becker, Pneumonitis-associated hyperprocalcitoninemia, Am. J. Med. Sci. 312, 12-18 (1996). DOI:10.1016/S0002-9629(15)41740-9.

[24] R. Wysokiński, K. Hernik, R. Szostak, D. Michalska, Electronic structure and vibrational spectra of cisdiammine(orotato)platinum(II), a potential cisplatin analogue: DFT and experimental study, Chem Phys., 333:37-48, 2007.

[25] A. D. Becke, Density-functional exchange-energy approximation with correct asymptotic behavior, Phys. Rev. A 38, 3098-3100 (1988). DOI:10.1103/PhysRevA.38.3098.

[26] A. D. Becke, Density-functional thermochemistry. III. The role of exact exchange, J. Chem. Phys. 98, 6485652 (1993). DOI:10.1063/1.464913.

[27] A. D. Becke, E. R. Johnson, A density-functional model of the dispersion interaction, J. Chem. Phys. 123, 154101-154103 (2005). DOI:10.1063/1.2065267.

[28] M. J. Frisch, G. W. Trucks, H. B. Schlegel, G. E. Scuseria, M. A. Robb, J. R. Cheeseman, G. Scalmani, V. 
Barone, B. Mennucci, G. A. Petersson, H. Nakatsuji, M. Caricato, X. Li, H. P. Hratchian, A. F. Izmaylov, J. Bloino, G. Zheng, J. L. Sonnenberg, M. Hada, M. Ehara, K. Toyota, R. Fukuda, J. Hasegawa, M. Ishida, T. Nakajima, Y. Honda, O. Kitao, H. Nakai, T. Vreven, J. A. Montgomery, Jr., J. E. Peralta, F. Ogliaro, M. Bearpark, J. J. Heyd, E. Brothers, K. N. Kudin, V. N. Staroverov, T. Keith, R. Kobayashi, J. Normand, K. Raghavachari, A. Rendell, J. C. Burant, S. S. Iyengar, J. Tomasi, M. Cossi, N. Rega, J. M. Millam, M. Klene, J. E. Knox, J. B. Cross, V. Bakken, C. Adamo, J. Jaramillo, R. Gomperts, R. E. Stratmann, O. Yazyev, A. J. Austin, R. Cammi, C. Pomelli, J. W. Ochterski, R. L. Martin, K. Morokuma, V. G. Zakrzewski, G. A. Voth, P. Salvador, J. J. Dannenberg, S. Dapprich, A. D. Daniels, O. Farkas, J. B. Foresman, J. V. Ortiz, J. Cioslowski, and D. J. Fox, Gaussian 09, Revision D.01 Gaussian, Inc.: Wallingford, CT, 2010.

[29] M. Sardo, R. Siegel, S. M. Santos, J. Rocha, J. R. B. Gomes, L. Mafra, Combining multinuclear highresolution solid-state MAS NMR and computational methods for resonance assignment of glutathione tripeptide, J. Phys. Chem. A 116, 6711-6719 (2012). DOI:10.1021/jp302128r.

[30] P. Ivanov, Performance of some DFT functionals with dispersion on modeling of the translational isomers of a solvent-switchable [2] rotaxane, J. Mol. Struct. 1107, 3138 (2016). DOI:10.1016/j.molstruc.2015.11.015.

[31] S. Grimme, S. Ehrlich, L. Goerigk, Effect of the damping function in dispersion corrected density functional theory, J. Comp. Chem. 32, 1456-1465 (2011). DOI:10.1002/jcc.21759.

[32] S. Grimme, J. Antony, S. Ehrlich, H. Krieg, A consistent and accurate ab initio parametrization of density functional dispersion correction (DFT-D) for the 94 elements H-Pu, J. Chem. Phys. 132, 154104-154107 (2010). DOI:10.1063/1.3382344.

[33] R. A. Munos, Y. N. Panchenko, G. S. Koptev, N. F Stepanov, Program for calculating distribution of potential energy in internal coordinates, J. Appl. Spectrosc. 12, 428-429 (1970).

[34] M. H. Jamróz, Vibrational energy distribution analysis VEDA 4, Warsaw, 2004.

[35] K. Wolinski, J. F. Hinton, P. Pulay, Efficient implementation of the gauge-independent atomic orbital method for NMR chemical shift calculations, J. Am. Chem. Soc. 112, 8251-8260 (1990). DOI:10.1021/ja00179a005.

[36] J. E. Carpenter, F. Weinhold, Analysis of the geometry of the hydroxymethyl radical by the "different hybrids for different spins" natural bond orbital procedure, $J$. Mol. Struct. THEOCHEM 169, 41-62 (1988).

[37] A. E. Reed, L. A. Curtiss, F. Weinhold, Intermolecular interactions from a natural bond orbital, donor-acceptor viewpoint, Chem. Rev. 88, 899-926 (1988). DOI:10.1021/cr00088a005.

[38] G. M. Morris, R. Huey, W. Lindstrom, M. F. Sanner, R. K. Belew, D. S. Goodsell, A.J. Olson, AutoDock4 and AutoDockTools4: Automated docking with selective receptor flexibility, J. Comput. Chem. 30, 2785-2791 (2009). DOI:10.1002/jcc.21256.

[39] J. M. Le Moullec, A. Jullienne, J. Chenais, F. Lasmoles, J. M. Guliana, G. Milhaud, M. S. Moukhtar, The complete sequence of human preprocalcitonin, FEBS Lett. 167, 93 97 (1984). DOI:10.1016/0014-5793(84)80839-X.

[40] BIOVIA Discovery Studio v4.0, Accelrys Software, Inc., San Diego, 2016.

[41] T. Yokoyama, Y. Kosaka, M. Mizuguchi, Structural insight into the interactions between death-associated protein kinase 1 and natural flavonoids, J. Med. Chem. 58, 7400-7408 (2015). DOI:10.1021/acs.jmedchem.5b00893.

[42] R. Zieliński, H. Szymusiak, Application of DFT B3LYP/GIAO and B3LYP/CSGT methods for interpretation of NMR spectra of flavonoids, Pol. J. Food Nutr. Sci. 12, 157-162 (2003).

[43] J. M. Dimitrić Marković, D. Amić, B. Lučić, Z. S. Marković, Oxidation of kaempferol and its iron(III) complex by DPPH radicals: spectroscopic and theoretical study, Monatsh. Chem. 145, 557-563 (2014). DOI:10.1007/s00706-013-1135-z.

[44] J. M. Dimitrić Marković, D. Milenković, D. Amić, A. Popović-Bijelić, M. Mojović, I. A. Pašti, Z. S. Marković, Energy requirements of the reactions of kaempferol and selected radical species in different media: towards the prediction of the possible radical scavenging mechanisms, Struct. Chem. 25, 1795-1804 (2014). DOI:10.1007/s11224-014-0453-z.

[45] J. S. Murray, K. D. Sen, Molecular Electrostatic Potentials : Concepts and Applications, Elsevier, Amsterdam, 1996.

[46] I. Alkorta, J. J. Perez, Molecular polarization potential maps of the nucleic acid bases, Int. J. Quantum Chem. 57, $123-135 \quad$ (1996). DOI:10.1002/(sici)1097461x(1996)57:1<123::aid-qua14>3.0.co;2-9.

[47] E. Scrocco, J. Tomasi, Electronic molecular structure, reactivity and intermolecular forces: A heuristic interpretation by means of electrostatic molecular potentials, Adv. Quantum Chem. 11, 116-193 (1978).

[48] F. J. Luque, M. Orozco, P. K. Bhadane, S. R. Gadre, SCRF calculation of the effect of water on the topology of the molecular electrostatic potential, J. Phys. Chem. 97, 9380-9384 (1993). DOI:10.1021/j100139a021.

[49] J. Šponer, P. Hobza, DNA base amino groups and their role in molecular interactions: Ab initio and preliminary density functional theory calculations, Int. J. Quantum Chem. 57, 959-970 (1996). DOI:10.1002/(SICI)1097461X(1996)57:5<959::AID-QUA16>3.0.CO;2-S.

[50] S. R. Gadre, I. H. Shrivastava, Shapes and sizes of molecular anions via topographical analysis of electrostatic potential, J. Chem. Phys. 94, 4384-4390 (1991). DOI:10.1063/1.460625.

[51] D. M. Burl, R. D. Miller, C. A. Walsh, Second-order nonlinearity in poled-polymer systems, Chem. Rev. 94, 31-75 (1994). DOI:10.1021/cr00025a002.

[52] C. Adant, M. Dupuis, J. L. Bredas, Ab initio study of the nonlinear optical properties of urea: Electron correlation and dispersion effects, Int. J. Quantum Chem. 56, 497507 (1995). DOI:10.1002/qua.560560853.

[53] M. Sikorska, I. Matławska, Kaempferol, isorhamnetin and their glycosides in the flowers of Asclepias syriaca L, Acta Pol. Pharm. 58, 269-272 (2001). 